\begin{tabular}{|c|c|c|c|}
\hline Eiszeitalter und Gegenvart & $\mathbf{5 3}$ & $\begin{array}{c}1-25 \\
27 \text { Abb., 2 Tab. }\end{array}$ & Hannover 2003 \\
\hline
\end{tabular}

\title{
Micromorphology and Site Formation at Hohle Fels Cave, Swabian Jura, Germany
}

\author{
Paul Goldberg, Solveig Schiegl, Karen Meligne, \\ Chris Dayton \& Nicholas J. ConarD*)
}

Keywords: caves, FTIR, micromorphology, Late Quaternary climate, Upper Palaeolithic

Abstract: Hohle Fels Cave near Schelklingen in the Swabian Jura area of southwestern Germany, contains an occupational and sedimentological record that spans at least the last 36,000 years and includes Aurignacian, Gravettian, and Magdalenian prehistoric occupations. The sediments were subjected to detailed micromorphological analysis coupled with microanalytical data using electron microprobe and FTIR techniques. The results show that much of the sediment has been derived from the interior of the cave where the finer matrix was partially phosphatized, likely derived from bear habitation. Moreover, the sediment has been subjected to cryoturbation and ice lensing under cold and damp conditions. These cold-related features become increasingly well developed in the Gravettian and Magdalenian layers reflecting more marked cooling during these periods. There is no evidence for the occupation of the cave by humans or cave bears during the Last Glacial Maximum. These geoarchaeological observations can be used test hypotheses about paleoclimate and human behavior developed using independent lines of evidence provided from botanical, faunal and archaeological materials. Some of the methods employed in this research have not previously been used to study the caves of the Swabian Jura and provide key new insights into the archaeological and natural history of the region.

"Anschrift der Verfasser: P. Goldberg, K. MELigne, C. Dayton: Department of Archaeology, Boston University, 675 Commonwealth Avenue, Boston Massachusetts 02215, U.S.A. E-mail: paulberg@bu.edu; N. ConARD, S. SCHIEGL: Institut für Ur- und Frühgeschichte und Archäologie des Mittelalters der Universität Tübingen, Abteilung für Ältere Urgeschichte und Quartärökologie, Schloss Hohentübingen, D-72070 Tübingen
Zusammenfassung: Die Höhle Hohle Fels liegt auf der Schwäbischen Alb bei Schelklingen und beinhaltet eine stratigraphische Folge, die mindestens 36.000 Jahre zurück geht und Aurignacien-, Gravettien- und Magdalenien-Fundschichten beinhaltet. Die Sedimente vom Hohle Fels wurden mit mikromorphologischen Analysen in Kombination mit Elektronmikroprobe und FTIR-Analysen untersucht. Die Ergebnisse zeigen, dass die Sedimente aus dem inneren Bereich der Höhle stammen und das die feine Matrix in Zusammenhang mit der Nutzung der Höhle durch Bären eine starke Phosphatenanreicherung erlebt hat. Mikrostrukturen belegen kalte und feuchte klimatische Phasen, chararkterisiert durch Kryoturbation und Eislinsen. Diese Merkmale sind in den Gravettien- und Magdalénien-Schichten stärker entwickelt und sprechen für kühle Bedingungen während dieser Perioden. Während des letzten Kältemaximums fehlen Hinweise für die Nutzung der Höhle durch Menschen und Höhlenbären. Diese Beobachtungen können als Grundlage dienen, um Hypothesen über das Paläoklima und über menschliches Verhalten im Paläolithikum, die anhand botanischer, faunistischer und archäologischer Daten entwickelt wurden, zu prüfen. Einige der Methoden dieser Untersuchungen wurden zum ersten Mal in den Höhlen der Schwäbischen Alb eingesetzt und lieferten viel versprechende Einblicke in die Archäologie und die naturhistorische Entwicklung der Region.

\section{Introduction}

Paleolithic excavations in the caves of the Swabian Jura have been conducted since the 1860s. This rich research tradition including the work of Oscar Fraas, R. R. Schmidt, Gustav Riek and others has its intellectual and 
methodological roots in the geosciences, and since its origins in the early 20th Century, the Department of Early Prehistory and Quaternary Ecology has had strong links to the geosciences of the University of Tübingen. Despite the long and successful research tradition in geoarchaeology in Tübingen, which includes recent work by J. Hahn, (Hahn 1988), H. Laville (Laville \& Hahn 1981) and I. CAMPEN (1987), it was not until the late 1990s that contemporary methods including micromorphological studies and microanalytical techniques, such as electron microprobe and FTIR have been applied to answer archaeological and paleoenvironmental questions related to the Paleolithic cave excavations in the Swabian Jura. With this paper we present a series of results using new methods to address research questions that range from site formation to environmental change, from the current excavations at Hohle Fels near Schelklingen in the Ach Valley of southwestern Germany.

\section{Site Setting and Stratigraphy}

Hohle Fels Cave is situated on the eastern extension of the Swabian Jura about $20 \mathrm{~km}$ west of Ulm (Figures 1 and 2). The cave is formed within an Upper Jurassic (Malm) limestone reef and occurs at about $534 \mathrm{~m}$ above sea level (asl) in the valley of the Ach River, a tributary of the Danube. The Ach Valley was cut by the Danube before it left its bed shortly during the Riss glacial maximum (VilLinger 1986). Today the Ach River is about $3 \mathrm{~m}$ wide and flows to the east into the blau river. Prior to the Riss Glacial Period the valley bottom was up to $40 \mathrm{~m}$ lower than today and much narrower; it has subsequently been filled with gravel and sand. The cave is located on the southeast side of the valley, about $7 \mathrm{~m}$ above the current valley bottom which here is about $350 \mathrm{~m}$ wide. During the terminal Pleistocene the valley bottom was ca. 5-10 m lower than today's position (WAGNER 1979).

Hohle Fels is one of the largest caves in the re-

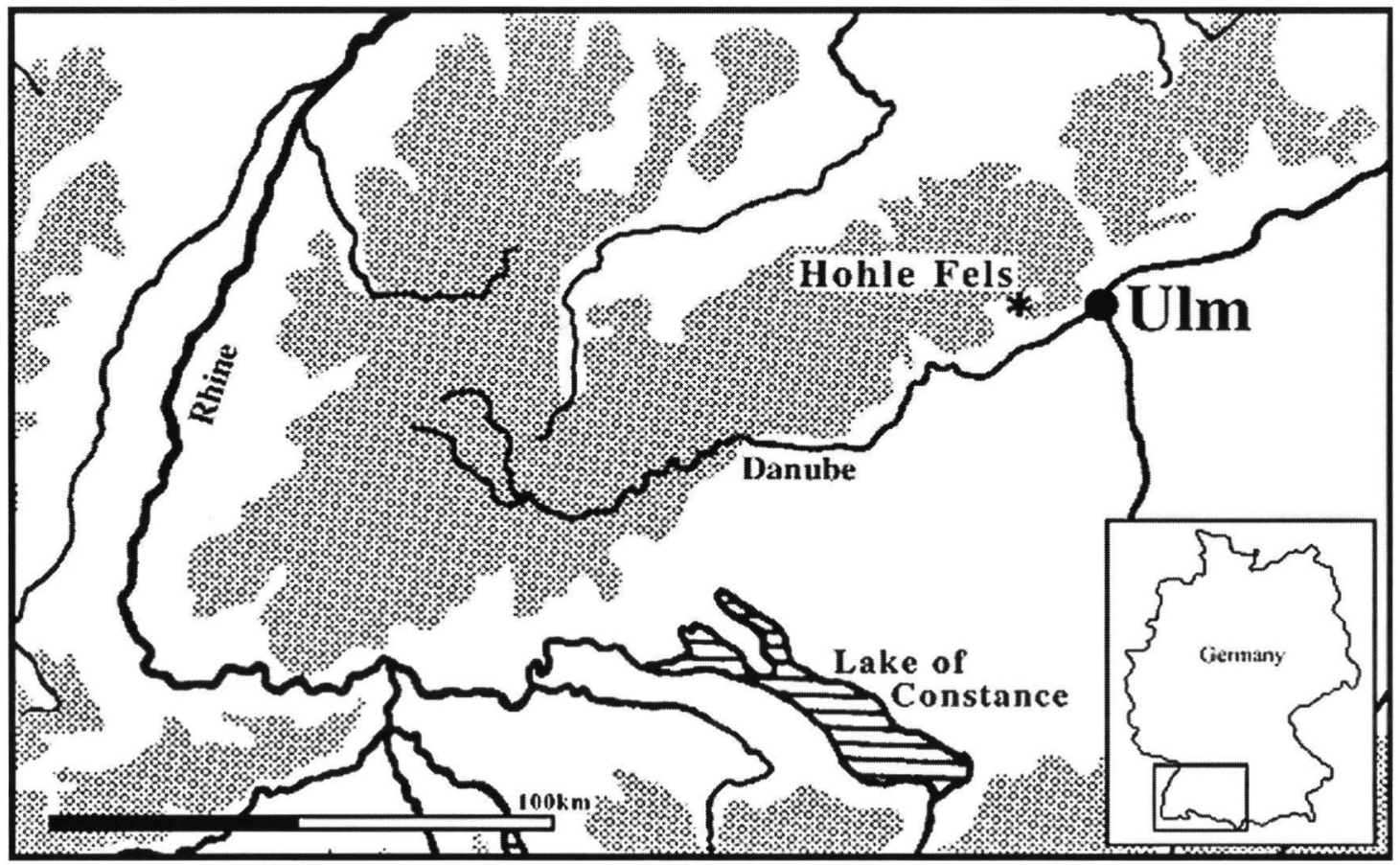

Fig. 1: Location Map of Hohle Fels Cave in the Swabian Jura. 
gion with a large cave hall that has a maximum height of $12 \mathrm{~m}$ and covers an area of $500 \mathrm{~m}^{2}$. The entrance is connected with the cave hall by a $30 \mathrm{~m}$ long passage (Figure 3 ). During the first scientific excavations in 1870/71 Oscar Fraas recovered an enormous number of cave bear bones, as well as stone, bone, and antler artifacts. R. R. Schmidt (SснміDт 1910, 1912) presented the Paleolithic from Hohle Fels in his classic monograph, „Die diluviale Vorzeit Deutschlands". From 1958-1960 G. Matschak and G. Riek conducted excavations in several parts of the cave, most notably in a large niche on the left side of the passage leading to the main hall of the cave. The excavators never published their results, and C. Saier (SAiER 1994) was the first to systematically study the finds from these excavations. Between 1977-79 and 1987-1996 Joachim Hahn renewed excavations in the niche in the hopes of gaining a stratigraphic section for comparison with the profile from nearby Geißenklösterle (HАнN 1988). Archaeological, palaeontological and geological research results from Hohle Fels have been published in numerous articles and theses (BLumentritT \& HaHN 1991; FISCHER et al. 1993; HAHN 1989a, 1989b, 1991, 1992, 1995; HAHN \& PASDA 1990; OBERMAIER 1906; RÄhle 1981; SCheER 1994). Since Hahn's death in 1997, N. Conard and H. P. Uerpmann have directed the ongoing excavations (Conard \& Uerpanan 1999; Conard \& Floss 1999, 2000; Conard et al. 2000, 2002). This latest work has revealed a sequence of éboulis-rich silty and clayey deposits, some rich in charcoal and burnt bone. In addition, a number of archaeological horizons were recognized that range from Aurignacian strata at the base through Gravettian and Magdalenian layers at the top (Figures 3, 4; Table 1).

The stratigraphic sequence at Hohle Fels can be considered from the standpoints of both lithoand archaeo-stratigraphy. The former approach results in several geological horizons $(\mathrm{GH})$ or Layers that follow standard field criteria based

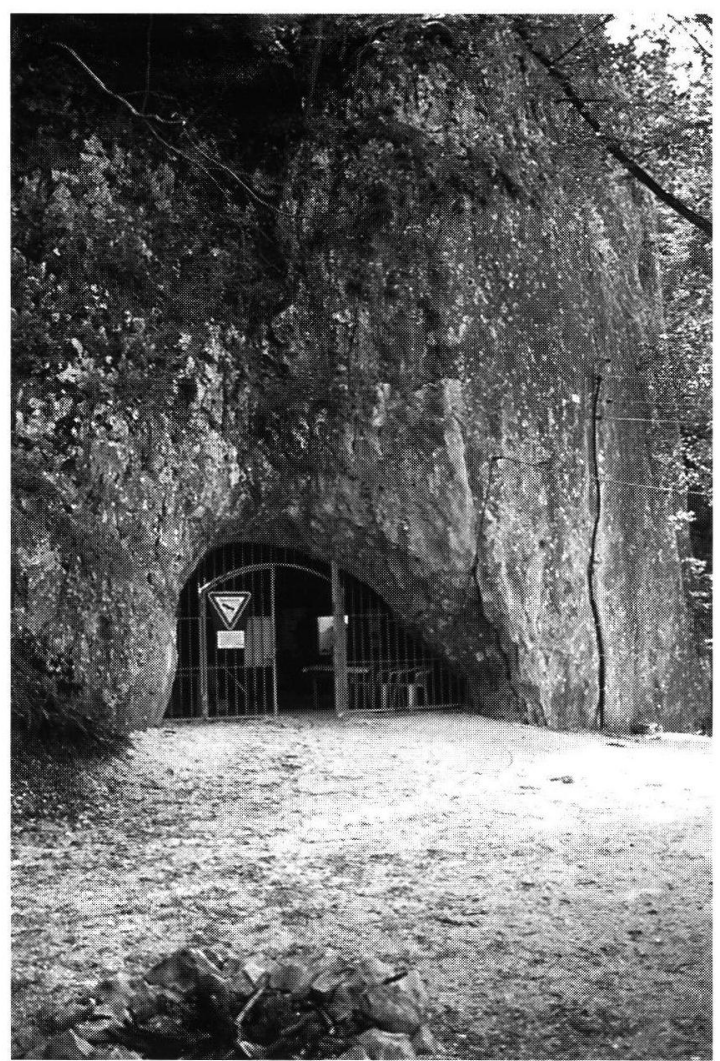

Fig. 2: Hohle Fels Cave entrance.

on parameters such as color, texture, and internal organization. These are described in Table 1. The archaeological horizons (AH) or Units, on the other hand, are determined on the basis of the assemblages of artifactual material. In the case of Hohle Fels, lithological and archaeological boundaries are strongly linked. At a more general level of analysis four main stratigraphic units (A-D) have been defined for operational reasons (Conard \& Uerpmann 1999; Table 1). Each of these units is discussed from bottom to top as follows:

Unit $D$ (the Aurignacian) - Unit $\mathrm{D}$ was uncovered over an area of $6 \mathrm{~m}^{2}$ (CONARD et al. 2002), and so far, consists of well stratified geological layers $3 \mathrm{~d}-8$ and archaeological horizons AH IIdV. Although we have not yet reached the bottom of this unit, thus far, about $1 \mathrm{~m}$ of sediments has been excavated (see CONARD et al. 2002). The majority of lithic artifacts was produced on 


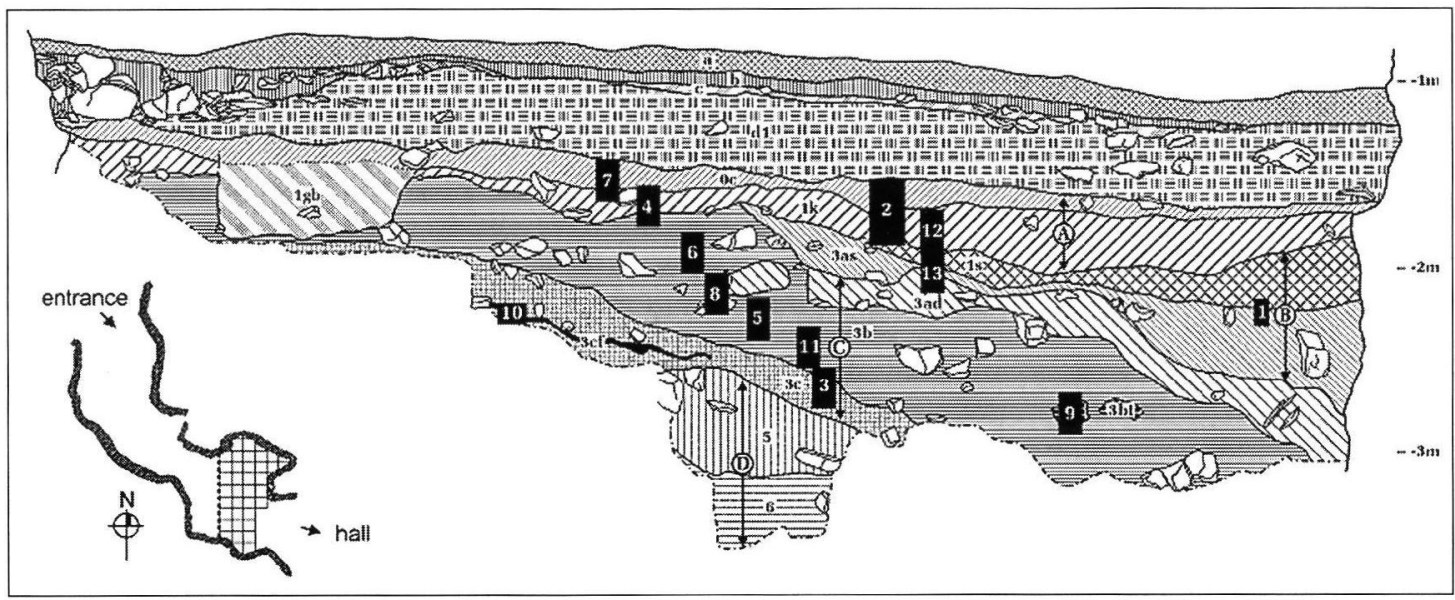

Fig. 3: Profile 2 showing stratigraphy with archaeological units and geological layers, as well as sampling locations. The inset map shows the deep interior chamber and the location of excavated area with exposures of sediments discussed in the text. The grid lines are $1 \mathrm{~m}$ apart.

local cherts. Unlike overlying Gravettian assemblages, implements made on radiolarite are considerably less abundant. Lack of debitage and cores suggests the absence of in situ knapping scatters, but discarded stone tools are common and include diverse forms typical for the Swabian Aurignacian. Implements and ornaments produced from ivory as well as ivory working debris are common, and three mammoth ivory figurines have been recovered from the Aurignacian layers from Hohle Fels. The faunal analysis is still underway, but preliminary analysis has documented the presence of mammoth, bear, horse, reindeer, fox, and hare. Furthermore, a well-defined concentration of burnt bone was unearthed in the lower Aurignacian horizon IV. A series of radiocarbon dates for these Aurignacian layers have yielded uncalibrated ages between 30 and $36 \mathrm{ka}$. These dates are consistent with the relatively early dates for the Aurignacian at nearby sites including Geißenklösterle (Conard \& Bolus in press). Geological samples from Unit D have not yet been studied.

Unit $C$ (the Gravettian) - The Gravettian layers $3 b-3 c f$ (AH IIb-IIcf), are $60-80 \mathrm{~cm}$ thick, and have been uncovered over an area of ca 30 $\mathrm{m}^{2}$. The sediments of these layers are well preserved, and many finds of these layers are from recognizable strata. The main occupation of the Gravettian complex dates to ca. 29,000 - 27,000 years BP.

More than $90 \%$ of the lithic assemblage is unmodified debitage. Cores and tools are also numerous, including backed knifes, burins, Gravette points, and end scrapers (CONARD et al. 2000). The lithic raw materials are similar to those of the Magdalenian tools (Burkert \& FLoss in press). A rich inventory of bone, antler and ivory tools as well as antler picks and perforated batons have been recovered (CONARD \& Floss 2001). The Gravettian archaeological horizons have yielded numerous pendants of ivory and perforated teeth.

The faunal record of the Gravettian layers has not been fully analyzed. Preliminary results show that cave bears are well represented, and in 2000 a vertebra of a cave bear was recovered from AH IIcf with an embedded fragment of a chert weapon. This find provides the first conclusive evidence for active hunting of cave bear. Nonetheless, the weight of evidence suggests that the majority of cave bear bone resulted from natural mortality (MünzEL et al. 2001). Horse appears to be the main game species, and reindeer is present but less abundant. As in the Aurignacian and Magdalenian deposits, much 
Tab. 1: Sediment and profile description of Hohle Fels Cave (Schelklingen, Southern Germany)

Profile 2 (cf. Fig. 4)

\begin{tabular}{|c|c|c|c|c|c|}
\hline $\begin{array}{l}\text { Geol. } \\
\text { Horizon/ } \\
\text { UNITS } \\
\end{array}$ & $\begin{array}{c}\text { Munsell } \\
\text { Color }\end{array}$ & Field observations & \begin{tabular}{|c|} 
Arch. \\
Horizon/ \\
LAYERS \\
\end{tabular} & \begin{tabular}{|c|}
$\begin{array}{c}\text { Archaeological } \\
\text { features and } \\
\text { Comments }\end{array}$ \\
\end{tabular} & $\begin{array}{c}\text { Uncalibrated }{ }^{14} \mathbf{C} \\
\text { Age } \\
\text { (AMS in italics) } \\
\end{array}$ \\
\hline \multicolumn{6}{|c|}{ 1. Modern Stratigraphic Complex } \\
\hline$a$ & $2.5 Y 7 / 4$ & $\begin{array}{l}\text { Cave pavement (Höhlenfestschichten) consisting of } \\
\text { alternating banded layers up to } 2 \mathrm{~cm} \text { in diameter; coarse } \\
\text { yellow, rectangular gravel and blackish fine sediment- } \\
\text { bearing pebbles. }\end{array}$ & 0 & & Post-1958 \\
\hline $\mathrm{b}$ & $5 Y 2.5 / 1$ & $\begin{array}{l}\text { Slag-bearing layer containing pebble chips and few } 3- \\
4 \mathrm{~cm} \text { size pebbles mixed with some finer clayey sediment }\end{array}$ & 0 & & 1944 \\
\hline C & $7.5 Y R$ 3/4 & $\begin{array}{l}\text { Thin gravel "leveling layer" with rounded pebbles up to } \\
2 \mathrm{~cm} \text { across. }\end{array}$ & 0 & & 1944 \\
\hline D1 & $2.5 Y 5 / 6$ & $\begin{array}{l}\text { Sandy sediment containing limestone gravel with } \\
\text { boulders up to } 45 \mathrm{~cm} \text { in diameter. Gravel displays } \\
\text { preferred sub-horizontal orientation. Yellow - ochre. }\end{array}$ & & & \\
\hline \multicolumn{6}{|c|}{ 2. Stratigraphic A - complex (Holocene; below Unit $1 \mathrm{k}$, pure and typical Magdalenian } \\
\hline Oc & $5 Y 2.5 / 1$ & $\begin{array}{l}\text { Slightly rounded to well rounded } 2-5 \mathrm{~cm} \text { size limestone } \\
\text { fragments lacking preferred orientation. They occur } \\
\text { within a dark grey/black argillaceous silt with fine- } \\
\text { grained calcareous sand. }\end{array}$ & $0 / 1$ & $\begin{array}{l}\text { Mixed horizon: } \\
\text { containing metal } \\
\text { age and Neolithic } \\
\text { ceramics and } \\
\text { Magdalenian } \\
\text { artefacts; } \\
\text { disturbed } \\
\text { Holocene surface } \\
\text { caused by } \\
\text { clearing in } 1944 \\
\end{array}$ & \\
\hline
\end{tabular}

\section{Magdalenian}

\begin{tabular}{|l|l|l|l|l|l|}
\hline Magdalenian & Clayey silt with 1-2 mm size irregularly to slightly \\
\hline $1 \mathrm{k}$ & $2.5 \mathrm{Y} 2 / 0$ & $\begin{array}{l}\text { rounded limestone gravel, slightly elongated and without } \\
\text { recognizable orientation. }\end{array}$ & I & $\begin{array}{l}\text { Magdalenian lithic } \\
\text { and organic } \\
\text { artifacts }\end{array}$ & $\begin{array}{l}13,240 \pm 110 \\
13,085 \pm 95 \\
12,770 \pm 220\end{array}$ \\
\hline
\end{tabular}

\section{Pit filling of Qu 76/77/86/87}

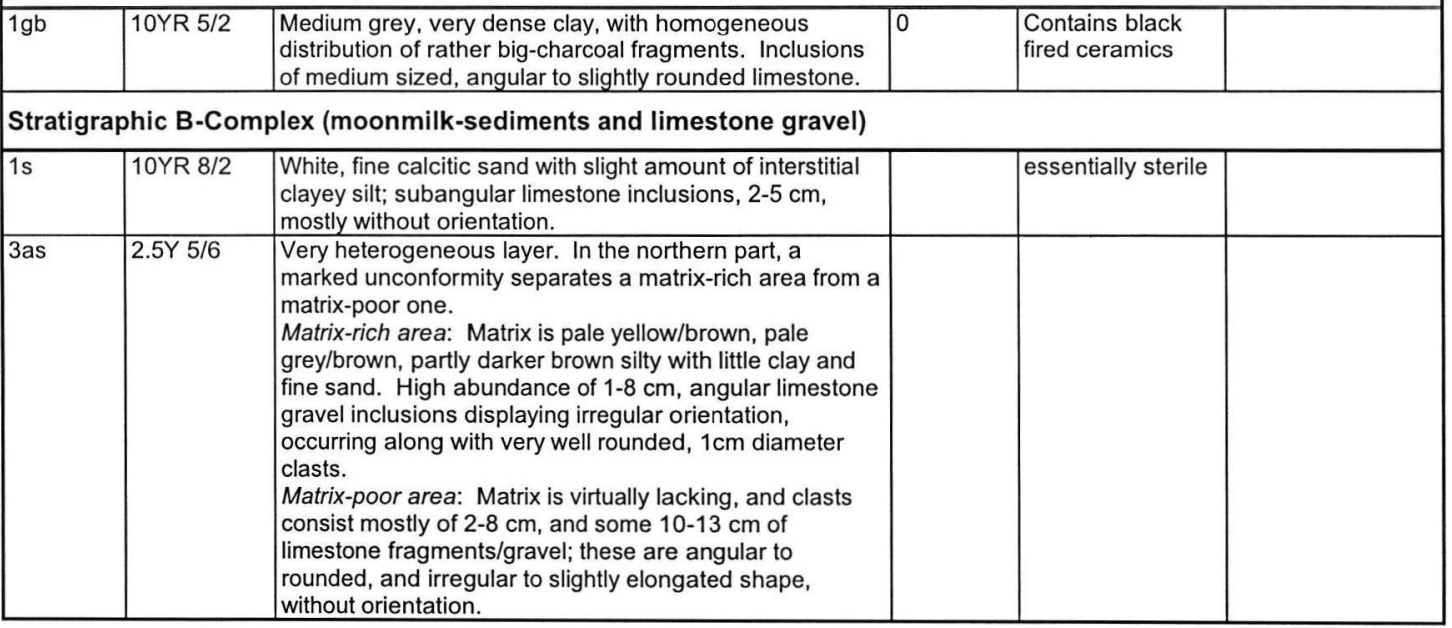




\begin{tabular}{|c|c|c|c|c|c|}
\hline \multicolumn{6}{|c|}{ Stratigraphic C-Complex (mainly Gravettian) } \\
\hline $3 \mathrm{ad}$ & 10YR3/2-4/4 & $\begin{array}{l}\text { Heterogeneous layer with pockets of variable brightness } \\
\text { (generated by washing out of finer components) } \\
\text { containing sedimentologically different types of infillings; } \\
\text { the darker sediment infillings possibly exhibit an } \\
\text { anthropogenic component. The lighter matrix consists of } \\
\text { dark grey-brown silt with small amounts of clay and } \\
\text { calcareous sand. The dark matrix is blackish silt with } \\
\text { small amounts of calcareous sand and a somewhat } \\
\text { higher clay component compared to areas of the bright } \\
\text { matrix. Inclusions }(2-7 \mathrm{~cm} \text { ) are relatively abundant, } \\
\text { mostly angular, but some partly rounded; they dip } \\
\text { northwards. }\end{array}$ & $1 / I \mathrm{lb}$ & \begin{tabular}{|l} 
Mixed \\
Magdalenian/Gra \\
vettian-horizon \\
(reworked and \\
displaced \\
Gravettian)
\end{tabular} & \\
\hline $\begin{array}{l}\text { 3b- } \\
\text { complex }\end{array}$ & $7.5 Y R 4 / 6$ & $\begin{array}{l}\text { Reddish silt with little clay and fine calcareous sand. } \\
\text { Inclusions of angular to slightly rounded limestone gravel } \\
\text { occur in variable amounts without orientation. }\end{array}$ & $11 \mathrm{~b}$ & $\begin{array}{l}\text { Gravettian lithic } \\
\text { and organic } \\
\text { artifacts }\end{array}$ & $27,150 \pm 600$ \\
\hline $3 b t$ & $2.5 Y 2 / 3$ & $\begin{array}{l}\text { Dark grey, partly black silt, with an abundance of sand } \\
\text { size burnt bone (Knochenkohle) and a small amount of } \\
\text { clay. Inclusions consist of some stones, bones and bone } \\
\text { ash }(>1 \mathrm{~cm}) \text {. }\end{array}$ & $11 \mathrm{~b}$ & $\begin{array}{l}\text { Gravettian lithic } \\
\text { and organic } \\
\text { artifacts }\end{array}$ & \\
\hline $3 c$ & 10YR5/6 & $\begin{array}{l}\text { Very moist clayey silt with many limestone clasts of } \\
\text { variable sizes. They are angular to rounded, and dip } \\
\text { towards the NE. }\end{array}$ & II C & $\begin{array}{l}\text { Gravettian lithic } \\
\text { and organic } \\
\text { artifacts }\end{array}$ & $29,550 \pm 650$ \\
\hline $3 c f$ & $5 Y 2.5 / 1$ & $\begin{array}{l}\text { Black clayey silt with a high proportion of bone ash that } \\
\text { underlies a limestone-rich gravel layer. }\end{array}$ & II c & $\begin{array}{l}\text { Gravettian lithic } \\
\text { and organic } \\
\text { artifacts }\end{array}$ & $28,920 \pm 400$ \\
\hline \multicolumn{6}{|c|}{ Stratigraphic D-Complex (mainly Aurignacian) } \\
\hline $3 d$ & 10YR 4/4 & $\begin{array}{l}\text { Red-brown argillaceous silt with ca. } 60 \% \text { of } 4-8 \mathrm{~cm} \text {, } \\
\text { slightly rounded limestone gravel inclusions. Matrix only } \\
\text { slightly compacted, contains abundant small pores and } \\
\text { cavities. }\end{array}$ & II d & Aurignacian? & $\begin{array}{l}29,560+240 /-230 \\
30,010 \pm 220\end{array}$ \\
\hline 5 & 7.5YR 4/4 & $\begin{array}{l}\text { Generally loose mixture of angular limestone gravel and } \\
\text { moist clayey silt with a minor component of coarse } \\
\text { calcareous sand. }\end{array}$ & II e & $\begin{array}{l}\text { Aurignacian lithic } \\
\text { and organic } \\
\text { artifacts }\end{array}$ & \\
\hline 6 & 7.5YR 5/6 & $\begin{array}{l}\text { Rounded limestone gravel with little interstitial matrix. } \\
\text { Mostly coarse-grained calcareous sand, downward- } \\
\text { facing edges or fracture planes of limestone fragments } \\
\text { frequently bear grey clay crusts. }\end{array}$ & III & $\begin{array}{l}\text { Aurignacian lithic } \\
\text { and organic } \\
\text { artifacts }\end{array}$ & $\begin{array}{l}30,550 \pm 550 \\
31,100 \pm 600\end{array}$ \\
\hline
\end{tabular}

Notes on descriptions:

1) These are provisional descriptions based on unpublished work by J. Hahn (12.09.1994); Waiblinger (1997); N.J. Conard and T. Prindiville (02.09.1997); and P. Russell and N.J. Conard (09.98). The geological and archaeological horizons ( $\mathrm{GH}$ and $\mathrm{AH}$ ) serve as preliminary field descriptions and are subject to modification during future excavations.

2) Colors were determined using the Munsell Soil Color Chart on moist samples, both in the cave under artificial light conditions and outside the cave in natural light.

3) Differentiation of individual sediment units on the basis of their calcium carbonate contents was not possible due to the large number of limestone clasts.

4) ${ }^{14} \mathrm{C}$ ages are uncalibrated and compiled from Conard and Bolus (2003); Conard and Floss (2000); Hofreiter et al. (2002); and Housley et al. (1997).

of archaeofauna has been systematically burnt for fuel. Fragments of bone of large game, such as mammoth and rhinoceros are also present. Large, medium and small game, such as fox and hare played a prominent part of the human economy - including use of hides, raw material and food.

Unit B (archaeologically sterile) - Unit B consists of two layers (1s and 3as), which together reach a maximum thickness around $70 \mathrm{~cm}$ next to the wall of the cave in the northern part of the excavation (Figure 4); these deposits thin out toward the interior of the niche. In contrast to the other strata, the horizons of unit B are light colored. This feature is due to high proportions of rubble- and sand-sized limestone, and low amounts of clay, especially in the upper horizon. The B-complex is archaeologically nearly sterile and lacks datable material. 
The rare artifacts recovered from this complex are apparently not in situ and were likely incorporated into the sediment by cryoturbation. Consistent with its sterile nature, its sedimentological composition, and the radiocarbon dates from the over- and underlying deposits, the B-complex can be reasonably correlated with the Last Glacial Maximum. No clear evidence of occupation has been discovered so far in the Swabian Jura during this interval.

Unit A (the Magdalenian) - The Magdalenian complex has been excavated over an area of 30 $\mathrm{m}^{2}$ and has a thickness of 20-60 cm. Much of the sediments has been modified by cryoturbation inhibiting the establishment of a fine stratigraphy (CONARD \& Floss 2001). The upper layers also contain diverse finds from the Holocene, such as pottery, demonstrating that considerable mixing has occurred. The Magdalenian complex dates to ca. 13,000 years BP.

The lithic artifacts from the Magdalenian deposits include mostly blades and bladelets, although scrapers, burins, borer, backed knives and backed points have also been uncovered. They are produced mainly from local Jurassic chert and radiolarite, although non-local raw materials are also present (BURKERT \& Floss in press).

Numerous bone and antler tools, such as projectile points, one double-rowed harpoon and several needles also occur. The Magdalenian assemblage contains worked pieces of jet and ivory, as well as perforated snail shells and teeth. In 1998 excavations recovered a painted rock fragment, which might have been a painted piece of the cave wall, or alternatively, could have been mobile art (CONARD \& Uerpanan 1999).

Horse and reindeer were the most important game. In addition, the layers contain bones of many other mammals, among which fox and hare are abundant.

\section{Laboratory Methods}

\section{Samples and sample preparation}

Cave sediments are typically complex mixtures of cultural and geological materials that are commonly diagenetically altered (WEINER et al. 1995). We thus chose a micromorphological approach that includes the study of undisturbed samples by light microscopy coupled with SEM study and elemental analysis of the in tact sediments.

A set of thirteen large samples of undisturbed blocks of sediment was collected along the western profile of the excavated entrance section (Figures 3 and 4). An additional sample (no. 14) was taken in excavation square 77 , about 1 $\mathrm{m}$ away from the profile. The cave sediments characteristically contain major amounts of limestone gravel - $\mathrm{mm}$ to several $\mathrm{dm}$ in size - derived from the roof and walls of the cave. Sampling such stony deposits is difficult, and it was not possible to use Kubiena boxes. Instead, we jacketed large areas of sediment exposed in Profile 2 with burlap dipped in plaster of Paris. After the exposed part of the plaster jackets hardened, the block was carefully removed from the profile and the rear portion was similarly covered with plaster-impregnated burlap.

In the laboratory several $1-2 \mathrm{~cm}^{2}$ large windows were cut through the plaster prior to 6 weeks of drying at $60^{\circ} \mathrm{C}$ in a drying oven. After drying, the blocks were put into large containers and partly covered with a mixture of styrenebased polymeric resin (Viscovoss N50 S by Voss Chemie GmbH), styrene (Merck Eurolab $\mathrm{GmbH}$ ) and hardener (MEKP MEC, Voss Chemie $\mathrm{GmbH}$ ) in relative volume proportions $7: 3: 0.025$. The containers kept for $30 \mathrm{~min}$ utes under vacuum of $<200$ mbar (Vacutherm chamber, Heraeus Instruments). The samples were removed from the vacuum chamber, completely immersed in the resin mixture and then put back into the chamber where they were kept for 5 days under vacuum, followed by a 24-hour heating period at $60^{\circ} \mathrm{C}$. After impregnation, 


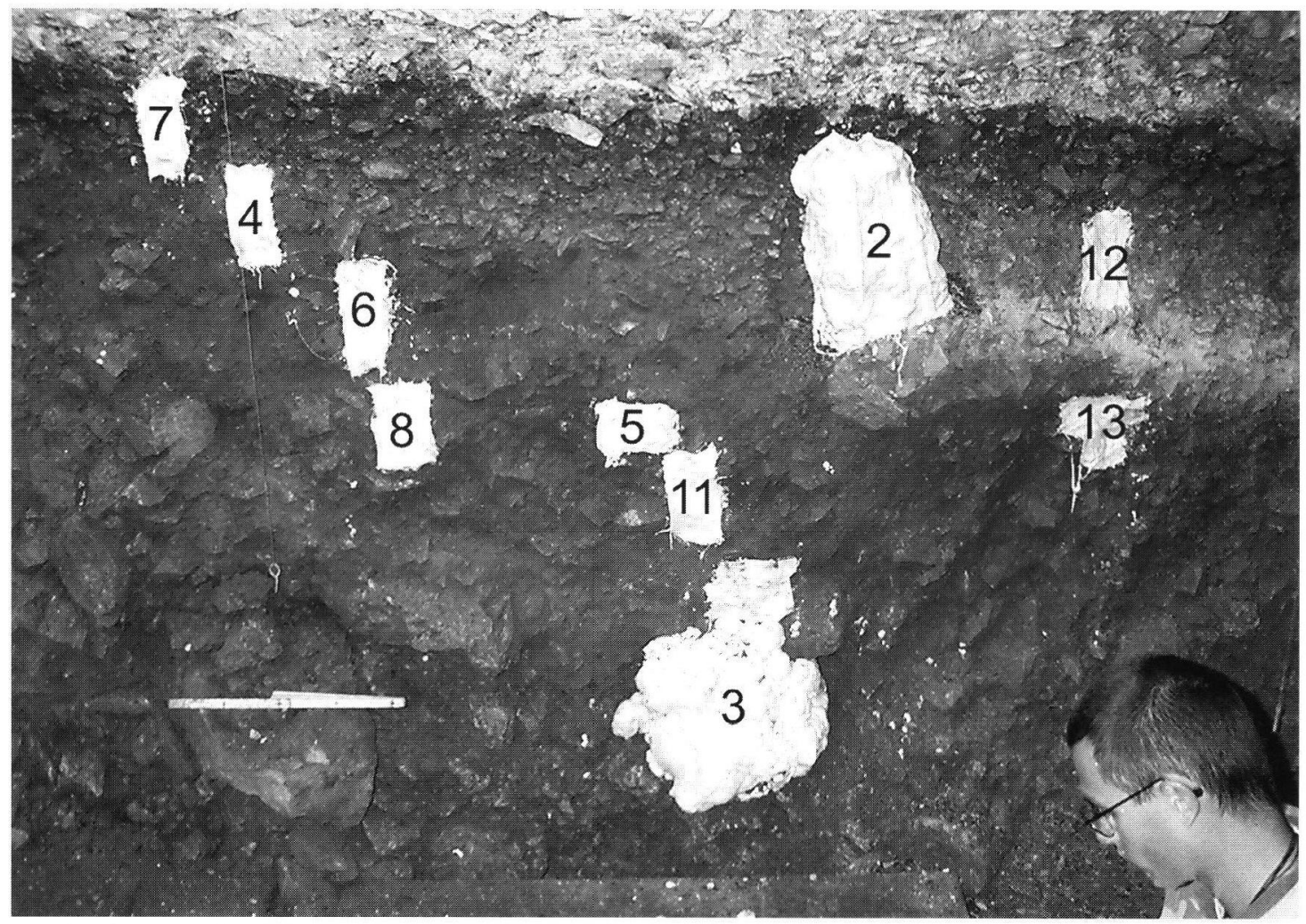

Fig. 4: Photograph of Profile 2 showing plaster-jacketed sediment samples. Compare with Figure 3.

several 1 to $2 \mathrm{~cm}$-thick slices were cut from each block by means of a water-cooled rock saw. Several representative areas were chosen from the slices for petrographic thin section preparation. Two series of thin section were produced, large sections of sizes of $7 \mathrm{~cm} \mathrm{x} 10 \mathrm{~cm}$ for transmitted light microscopy and smaller ones $(3.5 \mathrm{~cm} \times 2.5$ $\mathrm{cm}$ ) with highly polished surfaces for scanning electron microscopy.

In addition to the sample blocks, a second series of loose sediment were collected from corresponding localities for infrared spectroscopy. The latter were dried in a heating oven for several days at $60^{\circ} \mathrm{C}$.

\section{Analytical Methods}

Petrographic thin sections were observed with microfiche reader, transmitted polarizing light microscope, and electron microprobe analyzer (Jeol Superprobe JXA-8900R WD/ED Com- bined Microanalyzer). Optical examination of the thin sections consisted of observation with the microfiche reader at magnifications of ca. 10 to $20 \mathrm{x}$, and with the petrographic microscope at magnifications that ranged from $20 \mathrm{x}$ to $400 \mathrm{x}$. Such a strategy allows the section to be viewed at different scales, ranging from field to hand sample down to ultra-fine detail with the SEM (Courty et al. 1989).

The large thin sections were also scanned on a flat-bed scanner (ARPIN et al. 2002) in order to facilitate documentation for the microprobe. This procedure enables efficient location of spots analyzed by the electron microprobe analyzer, and in turn correlate electron microscope data with those obtained through polarizing light microscopy. Polished thin sections of the undisturbed sediments were carbon-coated and analyzed by Jeol Superprobe, equipped with energy dispersive (ED)- and wave length (WD) 
dispersive-analytical techniques (see SCHIEgl et al. in press, for details).

Finally, some of the loose samples of the burnt material from Layer $3 \mathrm{cf}$ (Figure 3 ) were analyzed by Fourier Transform Infrared Spectroscopy (FTIR; Nicolet Avatar 360 FT-IR E.S.P., computer-controlled by Omnic Version 5.1). FTIR spectra within the wavenumber-range between 400 and $4000 \mathrm{~cm}^{-1}$ were obtained by the potassium bromide $(\mathrm{KBr})$-pellet technique. Tens of micrograms of sample were finely ground using an agate mortar and pestle, and ca. $0.1 \mathrm{mg}$ of the sample powder was mixed with about 80 mg KBr (Uvasol by Merck, IR-grade). A $7 \mathrm{~mm}$ pellet was produced by means of a hand press without evacuation. The empty sample chamber was used as reference background. Thirty-two scans with a spectral resolution of $4 \mathrm{~cm}^{-1}$ spectra were carried out. If necessary, the baseline was corrected for measurements of the peak absorbances. Infrared-sensitive constituents were identified using a reference library containing more than 100 reference spectra relevant to archaeological samples.

\section{Results}

\section{Micromorphology}

The sediments from Hohle Fels Cave are more complex than they first appear on the macroscopic level in the field. The micromorphological examination of 17 thin sections from units $\mathrm{C}$ through A reveals fine variations of the texture, fabric and organization of the main constituents. Overall, the sediments are characterized by heterogeneity, which is itself expressed in different ways throughout the stratigraphic succession. The basic components, calcareous clay, lithic fragments, bone, charcoal and some fine organic material, are consistent through most of the sequence, although their organization and proportion change locally within the deposits. For the most part, the descriptions and discussion below refer to the geological/archaeological subdivisions within $\mathrm{C}$ to $\mathrm{A}$, the main units. The relevant subdivisions within Gravettian Unit $C$ are layers $3 \mathrm{c}, 3 \mathrm{~b}$ and their various subdivisions (Tables 1 and 2; Figure 4). Unit B is culturally sterile. The subdivisions within Unit A are Layers $1 \mathrm{k}$ and $0 \mathrm{c}$ and date to the Magdalenian and Holocene, respectively (Table 1; Figure 3).

\section{Coarse Fraction}

The coarse elements, defined as grains of sandsize and larger $(60 \mu \mathrm{m})$, consist of anthropogenic, geogenic, and biogenic components. The anthropogenic elements are burnt bone, some of the unburnt bone (if modified by humans), possibly coprolites, and charcoal. Geogenic components include limestone clasts and calcareous "ornaments" which crystallized on the roof and walls and were then detached. Two components of the coarse fraction could be attributed to both human and other biological agents: coprolites(/ phosphatic grains?) and unburnt bone. A few other minor constituents were observed in some of the thin sections: quartz grains, iron particles, and the coprolites mentioned above.

Bone, either burnt or unburnt, is nearly ubiquitous throughout the sediments, except in the culturally sterile Unit B (Table 2). While we found unburnt bone in all the Gravettian and Magdalenian layers, burnt bone was present in significant quantities only in layers $3 \mathrm{~b}, 3 \mathrm{bt}$, and $3 \mathrm{cf}$ of the Gravettian period. The size of the bone fragments ranges from unidentifiable splinters (as small as $20 \mu \mathrm{m}$ ) to $\mathrm{cm}$-long pieces. Several tooth fragments are also present and occur in the matrix or are incorporated within aggregates (Figure 5). Although they are mostly rounded - likely by cryoturbation - some bone fragments in aggregates remain very sharp and angular, suggesting reworking and transport of much of the bone (the significance of this bone layer is discussed below, and in detail in SCHIEGI. et al. 2003).

Charcoal is overall less common than burnt bone, being almost absent from the Gravettian sediments (Unit $\mathrm{C}$ ) and totally absent from the 
Tab. 2: Summary of Micromorphological Attributes of Sediments from Hohle Fels Cave

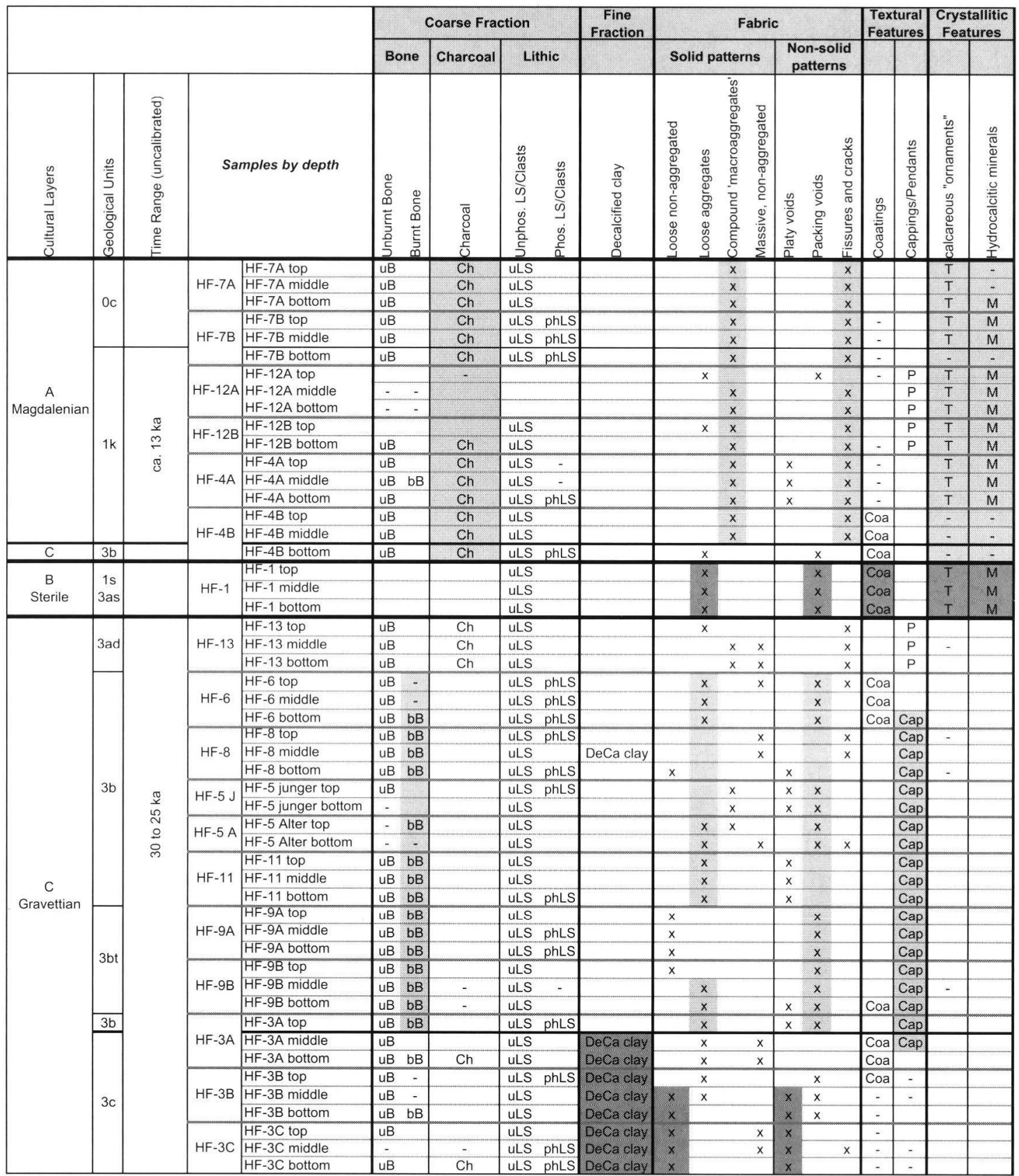

anthropogenically sterile sediments of Layer B (Table 2). Within the Gravettian sequence, only one layer contains significant amounts of charcoal: Layer $3 \mathrm{ad}$ at the top of the Gravettian sequence. On the other hand, most of the Magdalenian sediments (Unit A) were rich in charcoal fragments, which range in size from a few microns to a few millimeters. These fragments are either incorporated into the fine fraction or contained within rounded aggregates (Figure 5).

A portion of these charcoal fragments are 


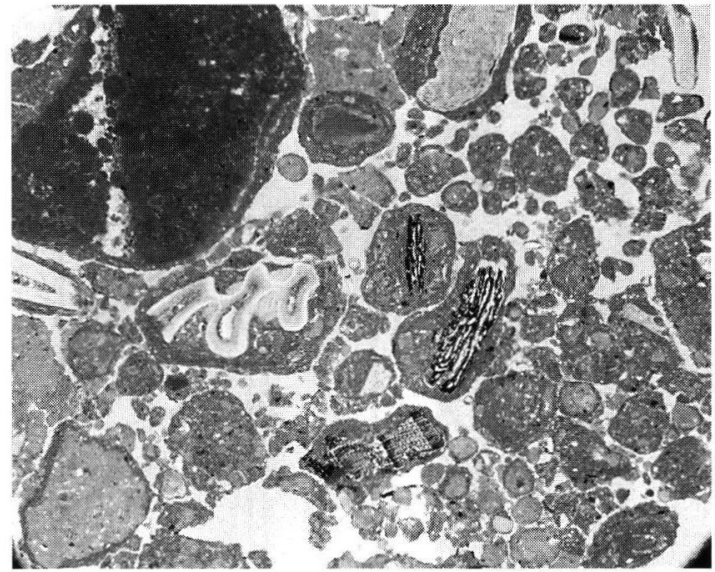

Fig. 5: Microphotograph of coarse, sand-sized clasts incorporated within rounded aggregates in sample HF-4B (Layer 3b). In particular, note the presence of charcoal fragments and rodent tooth in the center of the photograph. Plane-polarized light (PPL); width of view, ca. $3.2 \mathrm{~mm}$.

from Holocene deciduous trees, particularly beech (Fagus) and have been reworked into the Magdalenian deposits. Fragments of birch (Betula) and willow (Salix) appear to be of Pleistocene origin (These were identified by S. Riehl. The masses of beech clearly stem from Holocene features).

The Aurignacian layers (Unit D; analyzed by Freddy Damblon in Brussels) have birch, pine and even beech. The presence of the latter suggests a warm interstadial during this time; its occurrence in the Magdalenian - a cold period - is clearly intrusive.

The lithoclastic component consists almost exclusively of limestone fragments, and some calcareous, ornaments' (cf. crystallitic features below). Diverse types of limestone are present throughout the sediments, including oolitic and dolomitic limestone. They vary from sand to pebble size, and from subangular to rounded. An interesting feature of some limestone fragments is their partial phosphatization, which is manifested in plane polarized light (PPL) by a yellow-brown reaction rim along the edge of the grain (Figure 6); these rims are isotropic in

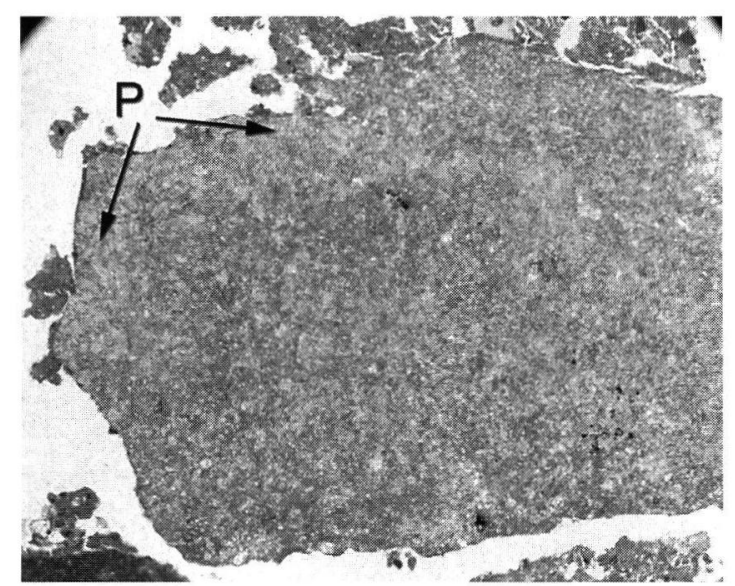

Fig: 6: Microphotograph of sample HF-3C (Layer $3 c)$ showing partially phosphatized limestone grain revealed by slightly lighter color on left and upper part of the grain ( $\mathrm{P}$ with arrows; this is yellow-brown in color photograph). PPL; width of view, ca. $3.2 \mathrm{~mm}$.

cross-polarized light (XPL). In ultraviolet light, the phosphatized portions fluoresce strongly, while the non phosphatized limestone „core“ of the grains does not. Phosphatic replacement of calcite is also manifested by tooth-like, etched terminations of calcite (Figures 7a, 7b). Phosphatization of calcareous grains does not appear to follow a specific stratigraphic pattern, and it may be that phosphatization occurs in localized areas throughout the entire sequence. Ambercolored phosphatic grains of indeterminate, but likely biogenic, origin occur in all samples (Table 2; Figures 8a, 8b).

\section{Fine Fraction}

The fine fraction consists of a yellow-brown to brown calcareous and locally phosphatic clay. Rare silt size inclusions of quartz grains, ambercolored phosphatic grains, and organic material - as well as silt-size fragments of the bone and charcoal described above - are embedded within the clay.

Although this calcareous clay is present throughout the sequence, the matrix in Layer $3 c$ clearly differs from that of any other layers 


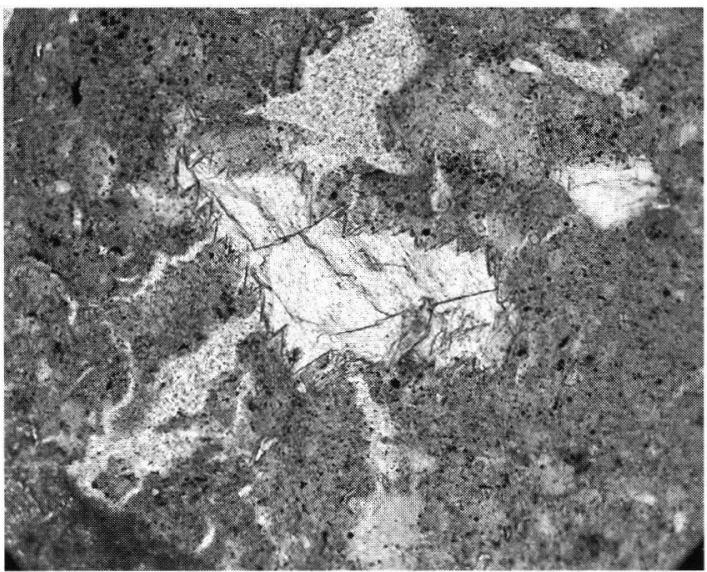

Fig. 7a: Microphotograph of phosphatized and etched calcite grain from sample HF-3C (Layer 3c). Etching of the calcite and replacement by phosphate creates an tooth-like pattern on the edge of the grain. PPL; width of view, ca. $650 \mu \mathrm{m}$.

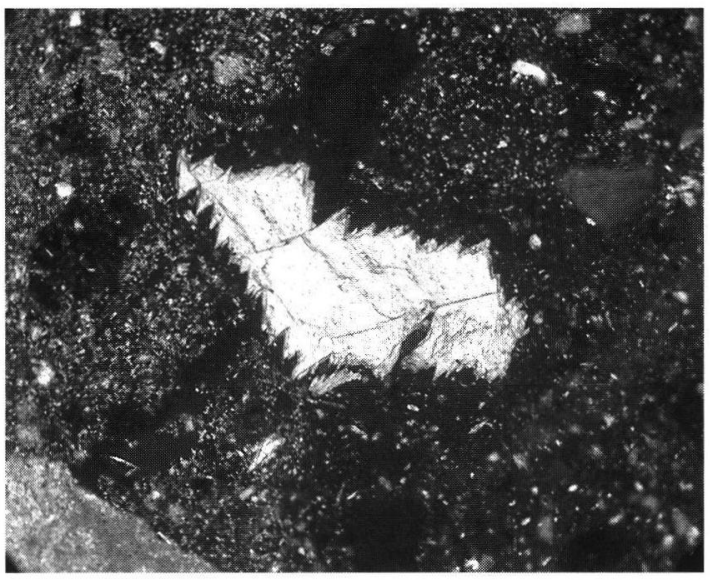

Fig. 7b: XPL

(Table 2). Layer $3 \mathrm{c}$ is characterized by localized domains of decalcified clay that appear within the generally calcareous matrix (Figure 9a, 9b). The frequency of the decalcified domains decreases upward within Layer 3c, from sample $\mathrm{HF}-3 \mathrm{C}$ to the middle of sample HF-3A. An isolated zone of decalcified matrix is also observed in sample HF-8 (Layer 3b) but it is local-

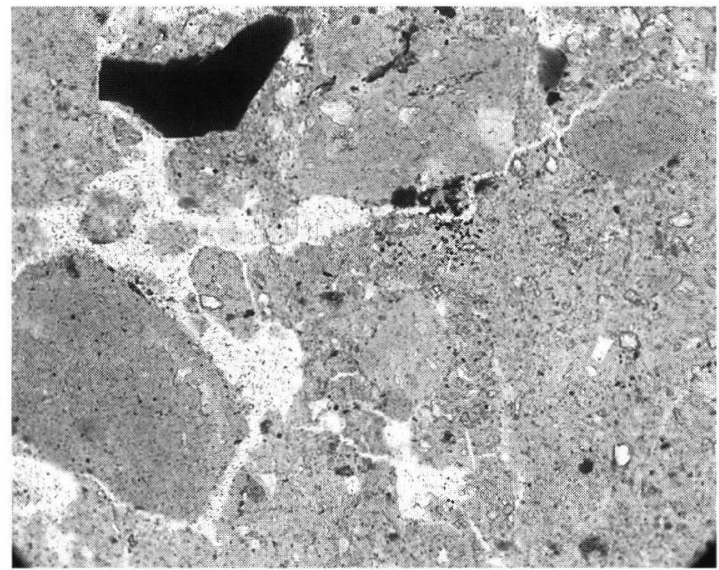

Fig. 8a: Microphotograph of slightly darker, amber-colored phosphatic grains in sample HF-8 (Layer 3b). Note their isotropic nature and the siltsize inclusions of quartz in XPL. They appear to represent phosphatic clays that have been reworked by cryoturbation or movement of material from within the main hall of the cave. PPL; width of view, ca. $650 \mu \mathrm{m}$.

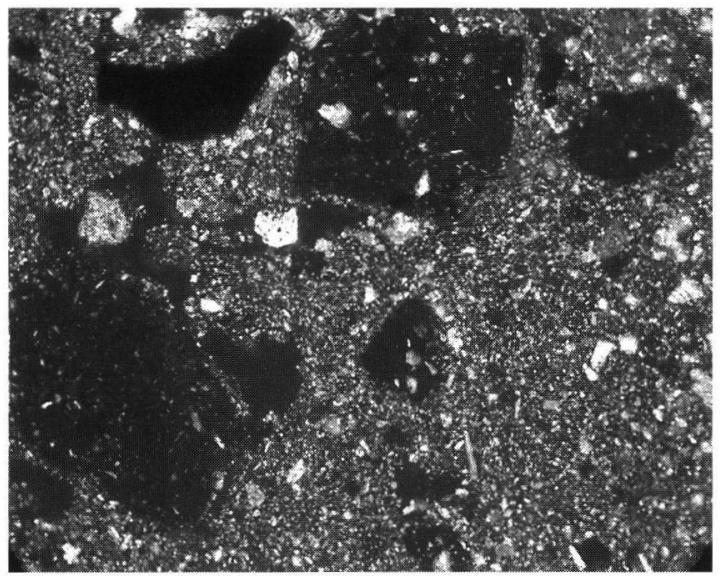

Fig. 8b: XPL.

ized and seems to be an exception. The domains of decalcified clay are therefore characteristic of Layer 3C only.

As discussed below, the dip of the deposits from the interior of the cave to the exterior clearly indicates that the clay is derived from the interior of the cave. Moreover, the clay appears to be ultimately derived from soil materials that were 


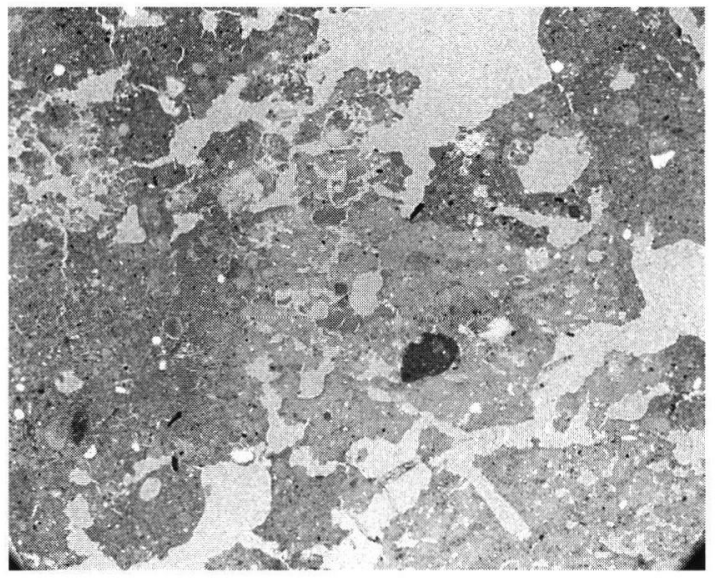

Fig. 9a: Sample HF-3C (Layer 3c). Microphotograph of a domain of decalcified clay within the generally calcareous matrix. While the matrix appears undifferentiated in plane-polarized light, crosspolarized examination reveals distinct domains of isotropic, decalcified clay. This decalcification of the matrix occurs only within Layer $3 c$ of the Gravettian complex. PPL; width of view, ca. $3.2 \mathrm{~mm}$.

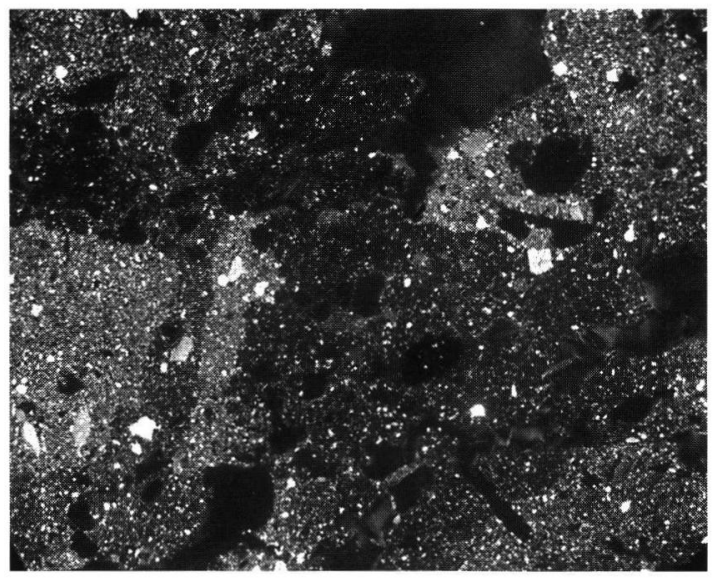

Fig. 9b: XPL

washed into the cave through openings in the roof, one of which can be seen at the back of the interior of the cave today. However, we were unable to obtain and analyze any modern soil material from the slopes above the cave since these slopes were denuded in historical (likely Medieval) times.

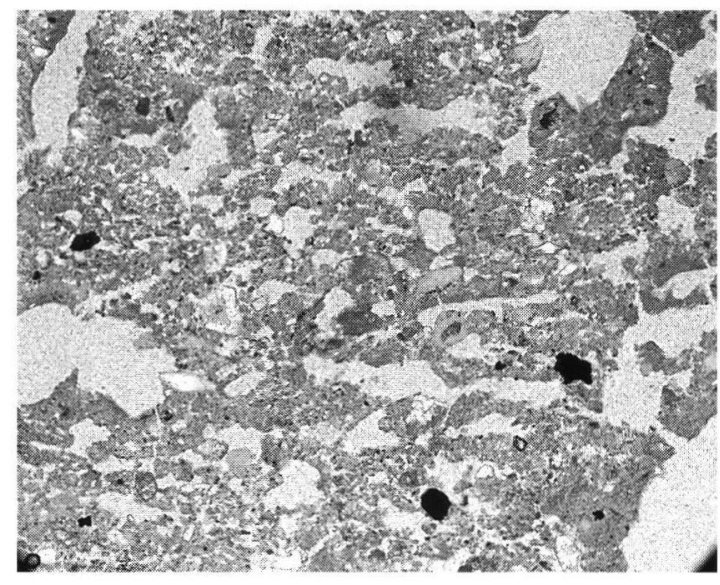

Fig. 10: Microphotograph of the loose, nonaggregated calcareous clay matrix within a moderately developed platy void structure in sample HF-3C (Layer 3c). The platy structure is created by ice lensing. PPL; width of view, ca. $1.6 \mathrm{~mm}$.

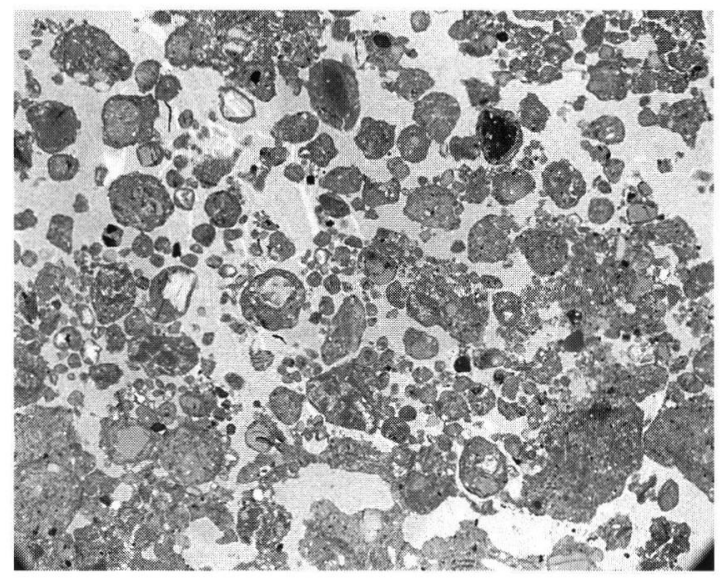

Fig. 11: Microphotograph of loose rounded aggregates in sample HF-3A (Layer 3b/3c) resulting from cryoturbation. The individual rounded aggregates are clearly separated and non compacted. PPL; width of view, ca. $3.2 \mathrm{~mm}$.

\section{Fabric}

As discussed above, the fine fraction is generally heterogeneous calcareous clay whose fabrics can be described as combinations of a small number of solid patterning (matrix) and non-solid patterning (voids). We divide the solid patterning into four modes of organization and the nonsolid patterning into three modes. 
Solid patterning: 1) This is simply a loose non-aggregated mix of clay and inclusions (Figure 10). 2) The second type is characterized by clearly defined individual rounded aggregates or , loose rounded aggregates' (Figure 11). These individual aggregates in some cases have a core composed of a coarse component, such as a fragment of bone, charcoal, or lithic material (see Figure 5). 3) In this case, the aggregates are compressed into more massive compound subangular, macroaggregates' (Figure 12). In such instances, the overall microstructure of the matrix is fissured or subangular blocky, and pedality of the material is evident. 4) Finally, the matrix also occurs as a massive, non-aggregated form, where the clay is relatively homogeneous compared to the type 3 , above (Figure 13).

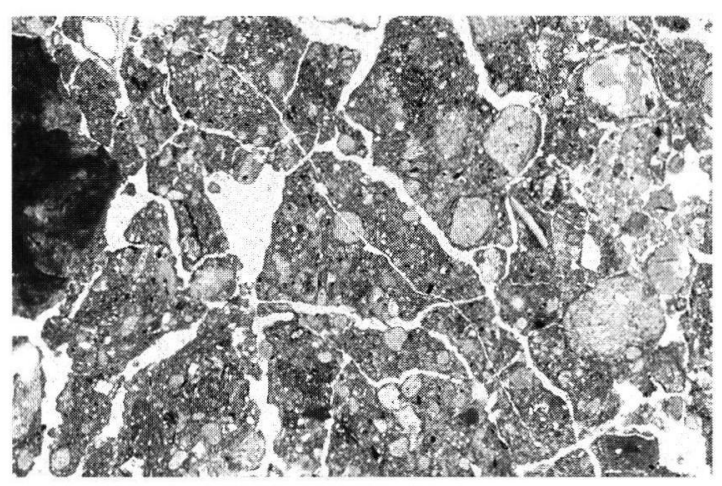

Fig. 12: Sample HF-7B (Layer 1k). Microphotograph of massive subangular macroaggregates associated with fissures and crack structure. The matrix, bounded by the fissures, are constituted of cryoturbated, rounded aggregates compacted together with some looser matrix material. PPL; width of view, ca. $3.2 \mathrm{~mm}$.

In addition, three types of non-solid patterning, i.e., organization patterns of the voids are very informative. 1) The first type is characterized by elongated voids, which give the matrix - whether aggregated or not - an overall platy appearance (Figure 10). As discussed below, such void structure results from ice lensing and is a typical manifestation of frost activity preserved in sediments and soils (VAN VLIET-LANOË 1982, 1985, 1987 , 1998). 2) Here, the void structure is relatively

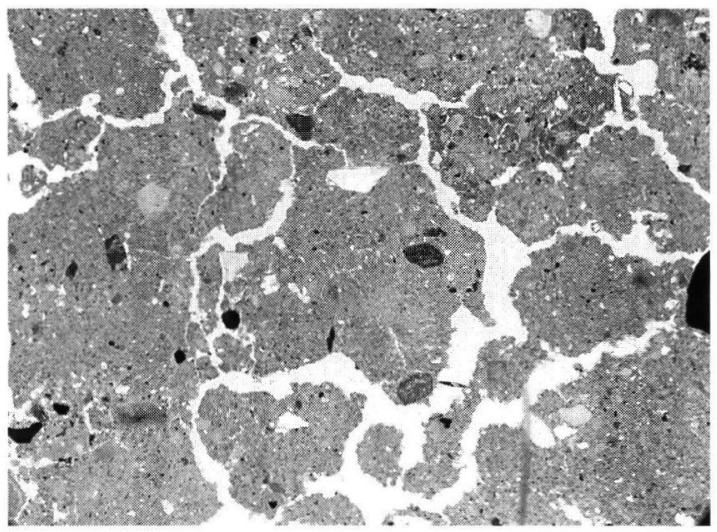

Fig: 13: Microphotograph of massive, non-aggregated and generally homogeneous clayey matrix associated with fissures and cracks from sample HF-8 (Layer 3b). PPL; width of view, ca. $3.2 \mathrm{~mm}$.

unpatterned, displaying irregular interstitial (packing) voids between singular and compound aggregates (Figure 11). 3) This last form is characterized by fissures and cracks (Figure 12).

In all thin sections examined, platy voids are generally encountered either with the loose nonaggregated matrix (Figure 10) or with the loose rounded aggregates (Figure 14; Table 2). Van Vliet-Lanoë (VAN VLIET-LANOË 1985) reports that platy structure due to ice lensing is best expressed in homogenous sandy substrates. In the case of Hohle Fels the heterogeneity of the sediments and the presence of large coarse elements - primarily and ultimately products of roof fall - makes the ice lensing structure less evident. However, the platy organization is still visible in localized domains.

The interstitial void structure is mostly an attribute of the loose rounded aggregates (Figure 11 ), and both patterns are characteristic of the effect of cryoturbation (VAN VLIET-LANOË 1982, 1987, 1991, 1998). Fissures and cracks, on the other hand, are associated with both the massive subangular macroaggregates (Figure 12) and with the massive non-aggregated matrix (Figure 13).

In this context of extreme heterogeneity, the different types of fabric tend to coexist within the 


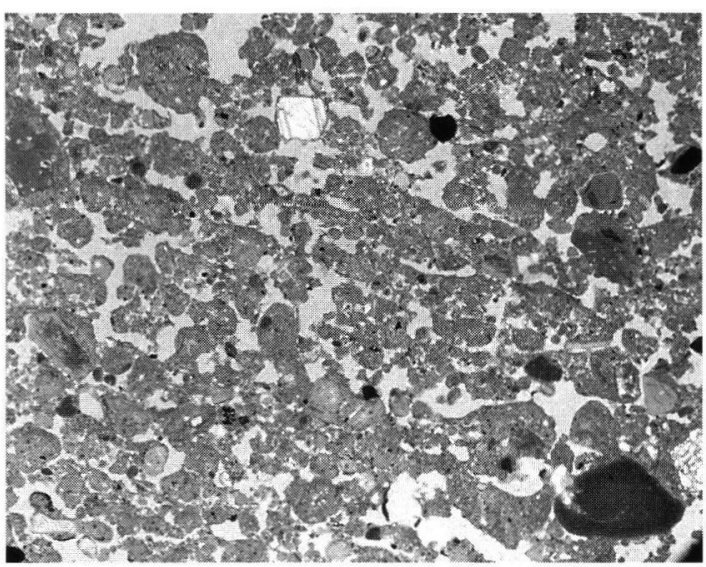

Fig. 14: Sample HF-11 (Layer 3b). Microphotograph of loose rounded aggregates within an overall platy void structure. The platy structure, caused by ice lensing, is superimposed on a matrix that has already been subjected to cryoturbation. PPL; width of view, ca. $3.2 \mathrm{~mm}$.

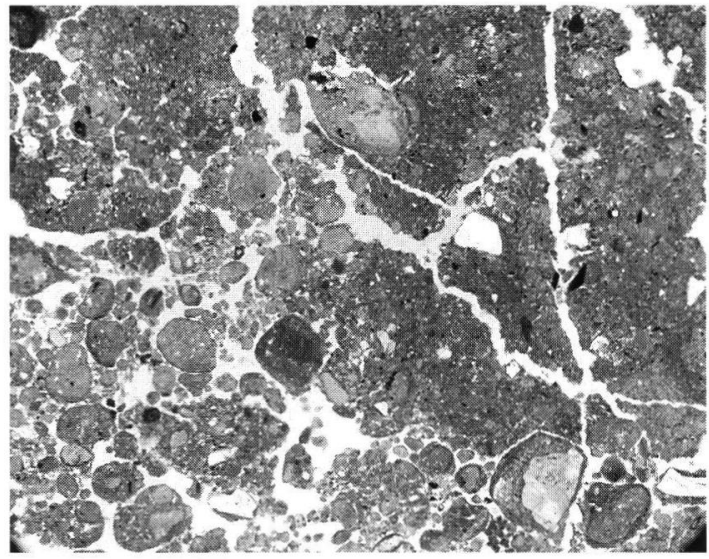

Fig. 15: Sample HF-4B (Layer 1k). Microphotograph of a contact zone between two different types of fabric, illustrating the extremely high variability of fabric types within a single sample. Isolated rounded aggregates occur in the lower portion, whereas the upper part of the photo shows more compacted, massive matrix material with fissured microstructure. PPL; width of view; ca. $3.2 \mathrm{~mm}$.

same thin section commonly being found adjacent to one another (Figure 15). Within each sample, however, it is possible to identify general fabric trends, as discussed below.

\section{Textural features}

Three varieties of textural or post-depositional features can be observed in thin section. Each type entails finely bedded matrix material - clay, organic matter, and fine lithic, bone and charcoal fragments - redistributed around coarse elements, such as aggregates or limestone clasts. The principal types of textural features include 1 ) coatings around the entire margins of coarse grains, 2) cappings on upper surfaces (Figure 16) and pendents on lower surfaces. Most coatings and cappings are poorly sorted, although they are finely bedded, except for overall coarser cappings in sample HF-5, which are constituted of sorted, inversely graded matrix material (Figure 17). Thick cappings are characteristic throughout the Gravettian 3b unit (Table 2). The pendents are rare, as they were observed only in samples HF12 and HF-13, both located on the right side of the profile, away from the central axis where most of the samples were taken.

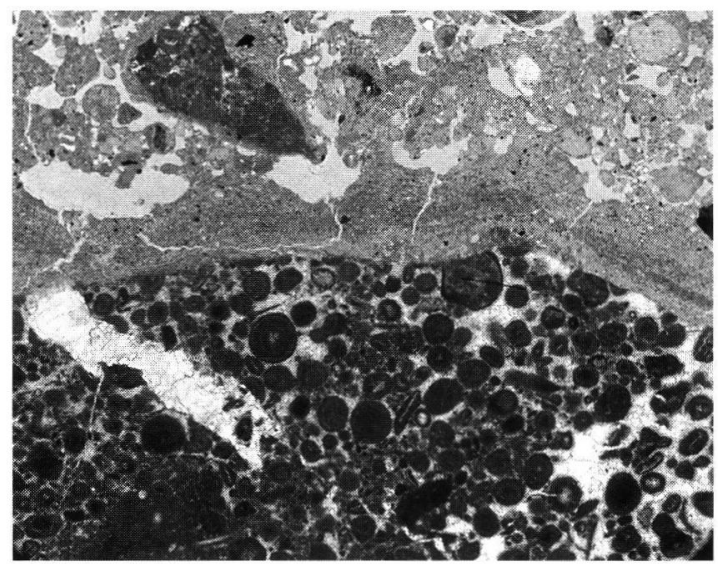

Fig. 16: Microphotograph of a thick, finely bedded silty capping in the central part of the photograph resting on a clast of oolitic limestone that makes up the lower half of the photograph; sample HF-3A (Layer 3b). PPL; width of view, ca. $3.2 \mathrm{~mm}$.

\section{Crystallitic features}

Samples HF-4, HF-7, and HF-12, collected from the Magdalenian layers (Layers $0 \mathrm{c}$ and $1 \mathrm{k}$ ), as well as sample HF-1 from the sterile Layers 


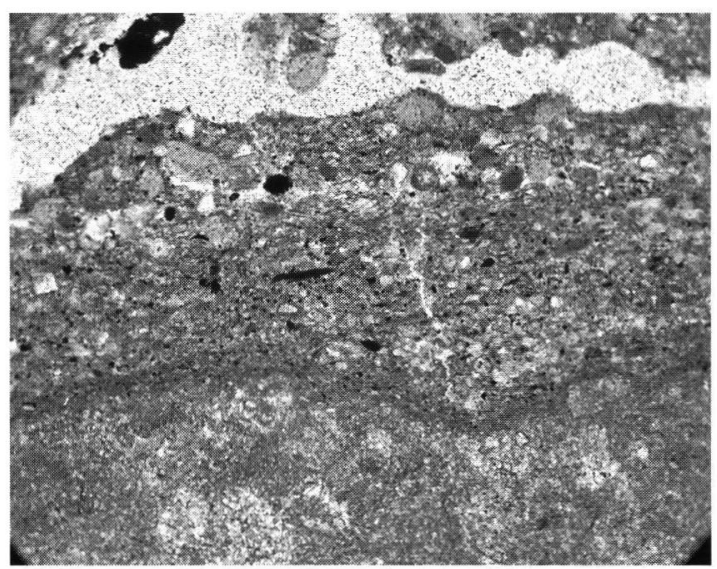

Fig. 17: Microphotograph of a poorly sorted coarse capping, consisting of quartz silt, rounded silt size phosphatic grains and aggregates and opaque minerals in black. Sample HF-5Alter (Layer 3b). PPL; width of view, ca. $650 \mu \mathrm{m}$.

(1s and 3as), contain two types of crystallitic features, calcareous ornaments and calcitic accumulations that were not observed in other layers.

The calcareous ,ornaments' consist of finely bedded calcareous precipitates in the form of isolated fragments or of coatings around limestone grains (Figure 18). They appear in finely deposited, undulating beds, and produce cauliflower-like formations. When examined under ultraviolet light, these calcareous precipitates are highly fluorescent, in contrast to the oolitic limestone fragments with which they are often associated. These ornaments appear to be fragments of material that precipitated along the cave walls, similar to stalactites, that later were dislodged from their original environment on the walls or ceiling of the cave.

The second crystallitic feature appears creamy white in PPL, and white to gray under XPL and is a calcite precipitate (identified by FTIR and SEM) (Figures 19a, 19b, 19c). Although

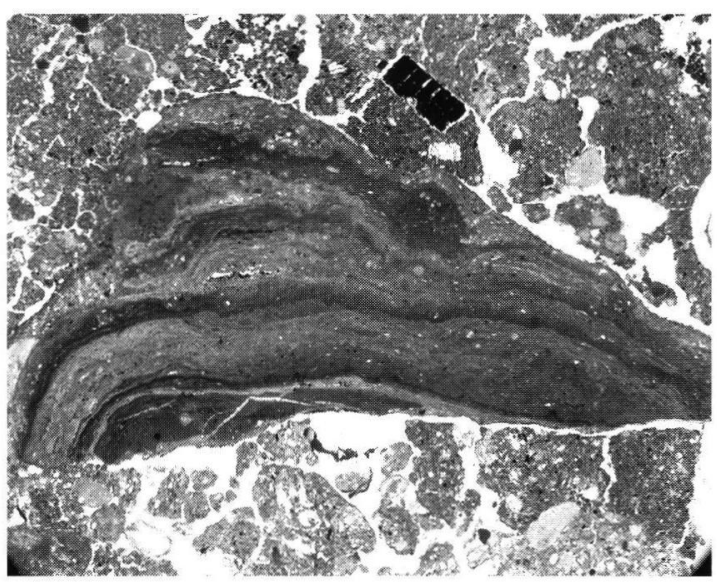

Fig. 18: Microphotograph of a microlayered calcareous, ornament'. Note the finely bedded precipitate with irregular form. The precipitate was originally arranged around a limestone clast (see remains fragment of oolitic limestone, bottom left). It either represents a broken pendent formed on the underside of rock resting on the floor of the cave, or more likely was probably detached from the walls or ceiling of the cave. Sample HF-7B. PPL; width of view, ca. $3.2 \mathrm{~mm}$.

most examples of this crystallitic feature have irregular shapes, a few are well rounded. The mineralogy is consistent with their moist, pasty feel in the field, similar to that of moonmilk (Gildieson 1997: 117, 122,126). These crystallitic features occur in the upper part of the stratigraphic section, mostly in Layers $1 \mathrm{~s}$, 3as and $1 \mathrm{k}$ (Figure 4; Tables 1 and 2).

\section{Discussion}

In the field, minor lithostratigraphic differences are evident in the exposed profile, mostly distinguishable by differing amounts of roof fall and slight color changes in the matrix. In general, the sediments appear to be similar (see Table 1 and Figure 4). However, examination of the thin sections provides a much greater level of resolution, revealing nuanced differences that provide significant insight into the geological history of the cave deposits. The overall pattern 

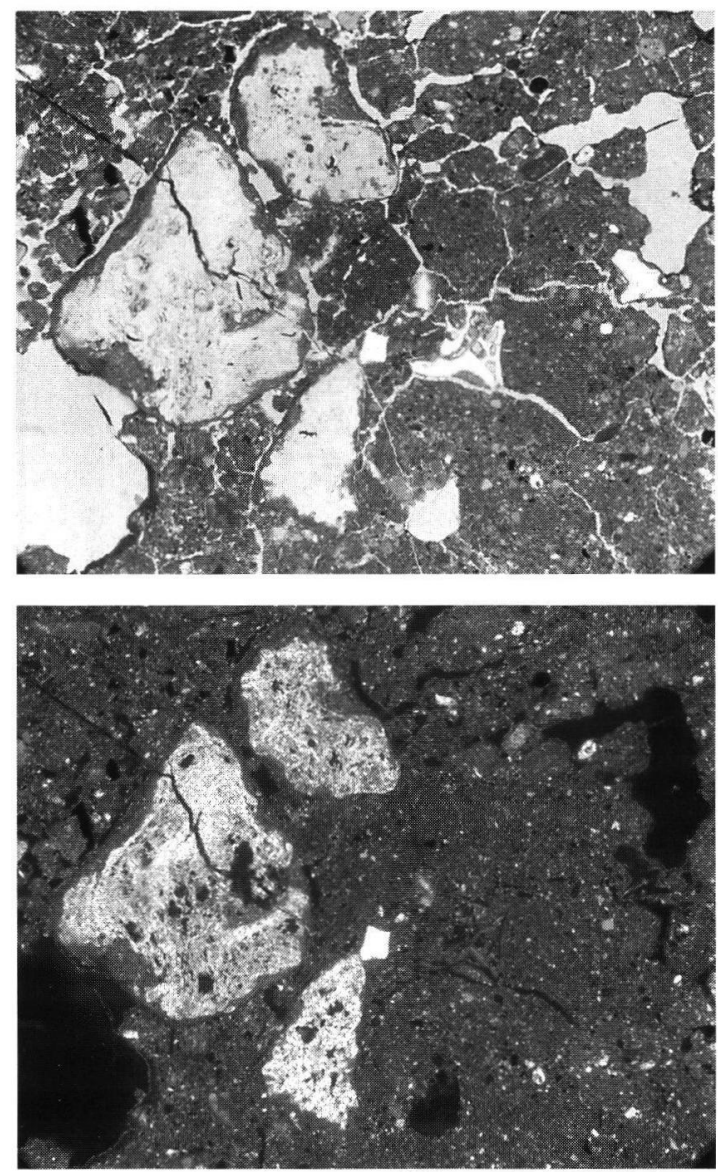

Fig. $19 \mathrm{a}+\mathrm{b}$ : Sample HF-7B (Layer $1 \mathrm{k} / 0 \mathrm{c}$ ) is from the upper part of the Hohle Fels profile, which is typically lighter in color. The microphotograph illustrates irregularly shaped, sub rounded precipitates of calcite, which are creamy white in PPL and white and gray under XPL. The surrounding fabric includes subangular macroaggregates associated with massive structure, fissures, and cracks. a) PPL, b) XPL; width of view, ca. $3.2 \mathrm{~mm}$.

of the results is presented in Table 2 . These patterns reflect changes in climatic conditions, anthropogenic activity, and other depositional and post-depositional processes discussed below.

\section{Climatic conditions}

The profile from which these samples were collected lies within the entrance passageway to the main chamber of the cave, and is approximately $20 \mathrm{~m}$ from the actual cave entrance (Figures 3 and 4). Nevertheless, the textural, compositional and fabric data demonstrate that climatic conditions - and their fluctuations - that existed outside the cave can be inferred from trends in these sediments. The current floor of the cave is about $2 \mathrm{~m}$ higher than it would have been in Gravettian times due to subsequent deposition of geological and anthropogenic material. Therefore the cave entrance would have been approximately 5 meters high in total, exposing it more fully to conditions outside and making the nature of the deposits more sensitive to climatic variations. The main hall of the cave has been heavily modified in historic times by "mining" for bear bones, phosphatic sediments, and by use as a military storage depot during the Second World War; in the interior hall, therefore, high quality Paleolithic data are not available. However, given the amount of climatic information preserved along the entrance passage, it seems likely that climatic variations also would have affected the main hall of the cave. Unfortunately, in the case of Hohle Fels this information is probably lost; the exact nature of frost activity inside the main hall remains unknown. Based on available evidence, human activities seem to have been focussed in the entrance passage which was sheltered from the elements, but where adequate daylight was available for diverse activities including stone knapping and bone and ivory working.

Viewed overall, one of the most striking features of the data is the clear unconformity within the Gravettian occupation between geological Layers $3 c$ and $3 b$ (Table 2). This unconformity is visible in terms of decalcification and phosphatization of the matrix, fabric, and textural features, although it is not evident in the ${ }^{14} \mathrm{C}$ dates.

Layer 3c, represented by samples HF-3C, HF$3 \mathrm{~B}$, and the lower portion of sample HF-3A, is marked by distinct decalcification of the clay matrix, which occurs in localized domains within the calcified matrix (Figure 9). Such alteration suggests an episode in which the sedi- 

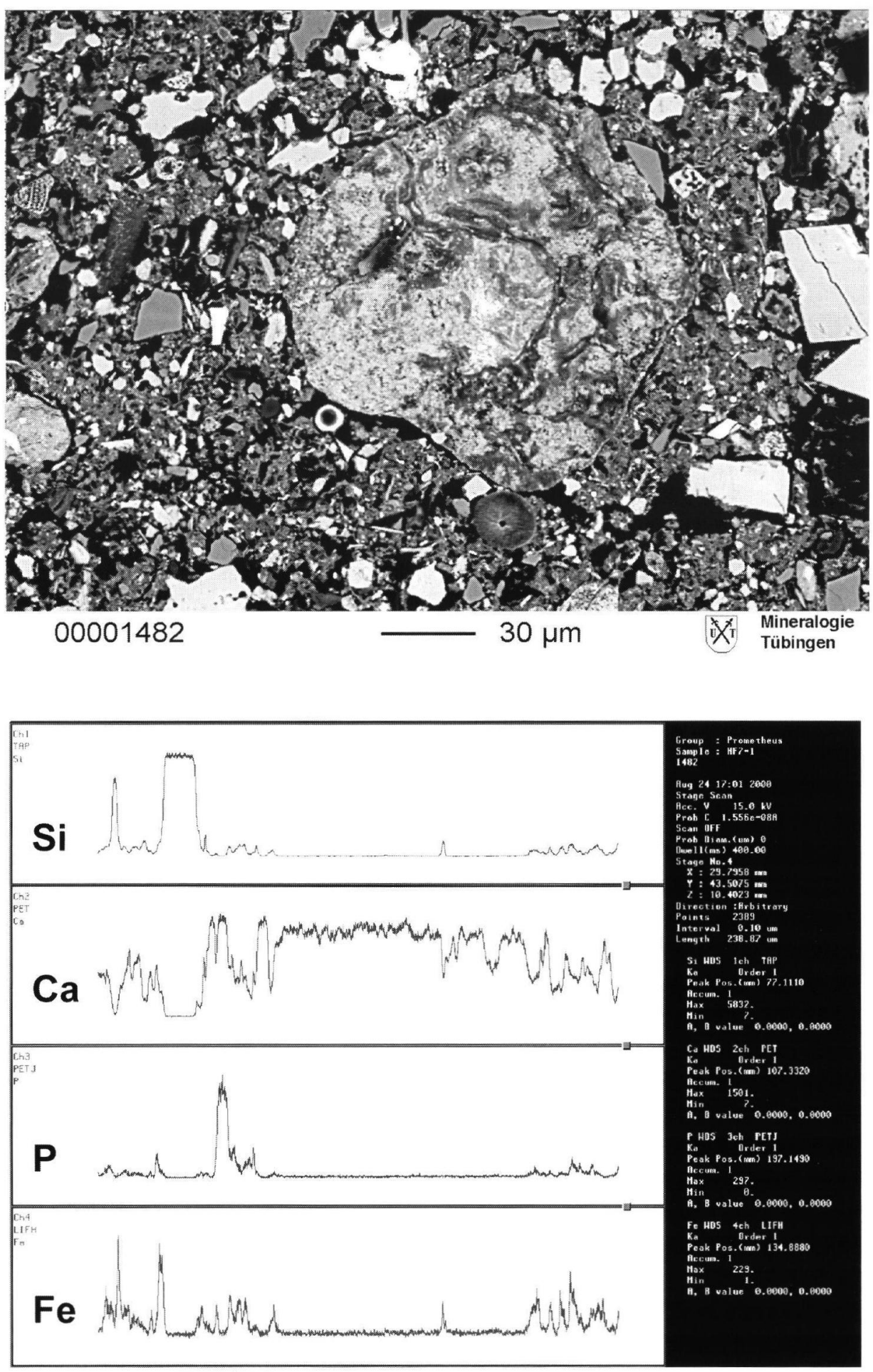

Fig. 19c: SEM BSE image of HF-7 with accompanying line scans shown in photo. Most of the scan is through the large, circular grain of calcite (cf. fig. 19a, b), but also includes grains of quartz (high Si peak) and bone (peak of $\mathrm{P}$ and $\mathrm{Ca}$ ). Iron is likely tied to the clay matrix. 
ments were exposed to weathering under acidic conditions, presumably associated with the decay of organic materials (e.g., vegetal material, guano). In contrast, the overlying sediments of Layer 3b, represented by samples HF-11, HF-5, HF-8 and HF-6, overall have a much "fresher“ appearance microscopically. While these upper sediments also contain a significant phosphatic fine component, the phosphate is primarily in the form of sand-size amber grains that are incorporated into fabric structures (Figure 12).

Fabric differences also serve to distinguish Layers $3 c$ and $3 b$. The samples from Layer $3 c$ are marked by loose, non-aggregated to loose aggregated arrangements of matrix, often displaying platy voids (Figure 10). These voids are characteristic of ice lensing in northern regions (VAN VLIET-LANOË 1982), and have been used as indicators of seasonal frost in cold paleoclimatic reconstructions (e.g., COURTY \& VALlverdu 2001; Cremaschi \& Van Vliet-Lanoë1990; Pissart et al. 1988a,. 1988b; VAn Vliet-Lanö̈ 1991). In the overlying Layer $3 \mathrm{~b}$, however, the matrix is arranged in loose rounded aggregates clearly separated by interstitial/packing voids, that in certain cases is superimposed by a platy microstructure (Figures 11 and 14). Such rounded aggregates and the general absence of ice lensing features point to cryoturbation (VAN Vliet-LanoË 1982, 1987, 1991, 1998). Moreover, the platy void structure observed in the sediments of Layer $3 \mathrm{~b}$ is superimposed on the already-present cryoturbated matrix, and suggests a later phase of ice lensing. It is difficult to determine a specific time frame for the duration of these processes as these processes can occur on the scale of seasons to decades.

Cryoturbation and the clear dip of the deposits from the main chamber toward the entrance (Figures 3 and 4) is responsible for transport of material from inside the cave outward. Unfortunately, due to modifications of the cave during the past century, and absence of excavation toward the interior, it is difficult to document the physical connection between the two areas.
Moreover, it is difficult to ascertain the ultimate source of the fine, clayey fraction of the sediments which must have come from well inside the cave system. It is likely either relict karstic, phreatically-derived material and/or soil material that has washed through openings and joints in the cave. Attempts to locate the origin of the fine fraction failed, in part hampered by the fact that soil material was completely stripped from the slopes above the cave in Medieval times. Until it was sealed in the1960s, a small chimney near the back of the cave, which was just big enough for people to climb through, connected the main hall with the hilltop above the cave. If this chimney existed during the Pleistocene, it helps to explain the source of the silt and clay that contributed to the sediment cone in the main hall and led to the oozing outward movement of clay and silt that characterized the overall sedimentary context of Hohle Fels.

Layer $3 \mathrm{~b}$ is also marked by cappings of fine material on larger clasts, bones and aggregates. Such capping can be explained in terms of clay migration during the spring thawing (VAN VLIET-LANOË 1985), and confirms that the sediments near the entrance of the cave were repeatedly exposed to freeze-thaw cycles during this time.

Finally, the unconformity between Layers $3 \mathrm{c}$ and $3 \mathrm{~b}$ is not visible in the numerous ${ }^{14} \mathrm{C}$ dates from the deposits. The clear boundary between Layers 3c and 3b, and this hiatus suggests that an unknown portion of $3 \mathrm{c}$ sediments was removed during this time, likely after the decalcification of the layer but before active sedimentation of the overlying Layer $3 \mathrm{~b}$ which took place in a regime of less extreme phosphate mobilization.

An additional trend in the results is the combined occurrence of two calcareous crystallitic features in the sterile unit B and in the Magdalenian complex, unit A. In general, the Magdalenian sediments are characterized by a more massive fabric of subangular ,macroaggregates' and by cracks and fissures (Figure 


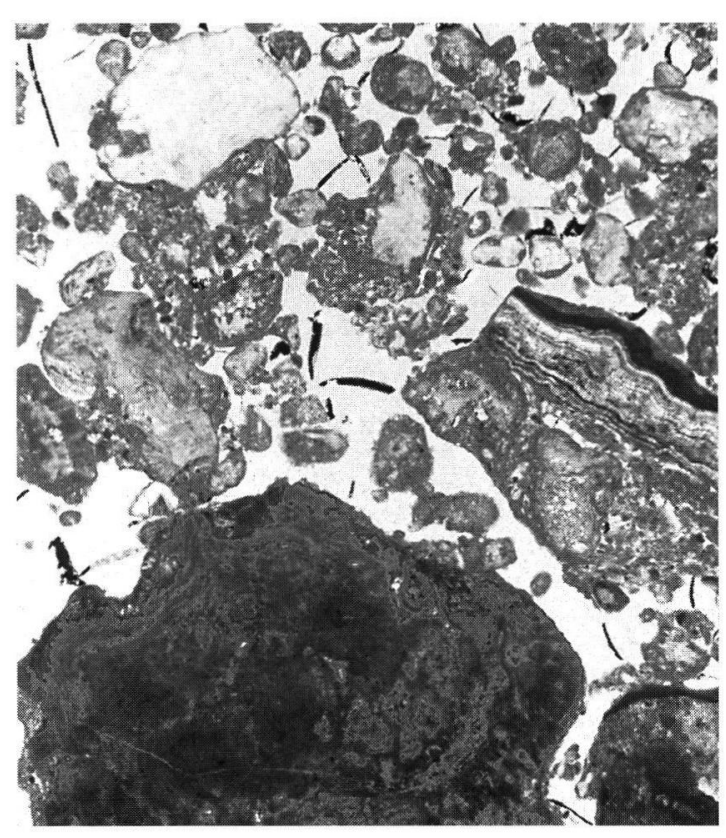

Fig. 20a: Microphotograph of the calcareous and calcitic matrix of the sterile layers, sample HF-1 (Layer 1s). The sample consists of bright, rounded masses of calcite and calcareous ornaments within a calcareous matrix. Note the cauliflower-type aggregate in the lower part of the photo, and the platy piece of bedded flowstone in the center right. PPL,

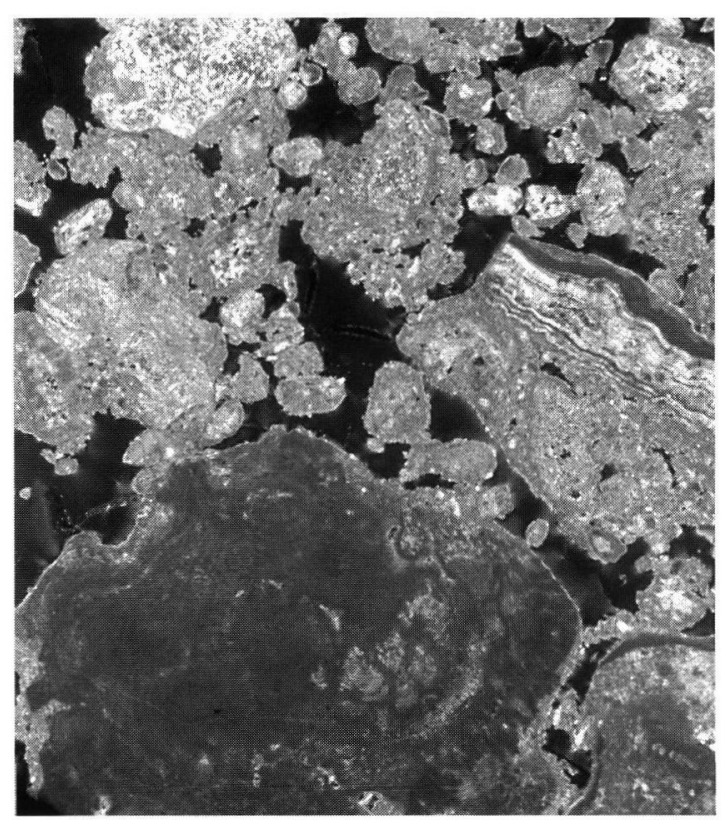

Fig. 20b: XPL; width of view, ca. $3.2 \mathrm{~mm}$.
12). While the capping observed in Layer $3 \mathrm{~b}$ disappears, coarse elements are often thinly coated and pendents occur in a few samples. The crystallitic features, however, are most noticeable. They consist of fragments of calcitic cauliflower-like ornaments and rounded masses of calcite. But overall the proportion of these two crystallitic features is particularly high in the sterile layer (Figure 20a, 20b), their concentration tends to increase upwards within the Magdalenian complex, with only rare traces in sample HF-4B (Layer $1 \mathrm{k}$ ) and high concentrations in sample $\mathrm{HF}-7 \mathrm{~B}, 7 \mathrm{~A}$ (Layers $0 \mathrm{c}$ and 1k) (Figure 4; Table 2). These two features are entirely absent from the older, Gravettian layers, and the question of their unique presence in the upper part of the sequence of the cave is intriguing and problematic. One interpretation is that they are related to a change of the overall climatic regime of the area. As such, dripping due to wetter and warmer (i.e., less freezing) climate could be responsible for the formation of both crystallitic structures. The Magdalenian predates the warmer Bölling and Alleröd periods which are then followed by the Younger Dryas cold period. However, the paragenesis of both of these secondary features is still under study. In sum, it is necessary to note that there is a substantial temporal gap at the LGM and the early dates for the Gravettian, coupled with a relatively long period of non-human-occupation of the cave until ca. $13 \mathrm{ka}$ b.p.

\section{Anthropogenic activity}

In the field, two main phases of Paleolithic occupation of the cave were identified between units A and C. Earlier occupation is attested in unit $D$, but there has been only limited excavation with micromorphological data for this older occupation.

In thin section, human presence is manifested mainly by the occurrence of bone fragments and charcoal. An interesting pattern emerged from the examination and comparison of samples from the Magdalenian and from the Gravettian 
phases of occupation. Charcoal is extremely rare in the Gravettian layers (Layer C), except from Layer 3ad, a dark layer situated at the very top of the Gravettian sequence (Table 2). Most of the Gravettian filling, therefore, is virtually devoid of charcoal. [S. Riehl has identified remains of willow (Salix) in Gravettian layers. Based on charcoal, pollen and phytoliths the Gravettian is characterized by grasses and shrubs and seems to be a cool and dry period. Willows are the only tree species thus far identified, and these are probably arctic shrub willow.] Burnt bone, on the other hand, is abundant through Layer $3 \mathrm{~b}$ and occasionally in Layer $3 \mathrm{c}$ of the Gravettian (Figure 21). The absence of charcoal in anthropogenic sediments containing such evidence of burning is certainly unusual. The reverse situation observed in the Magdalenian layers, where charcoal is abundant and burnt bone rare if not absent, might be considered more the expected case. (As mentioned above, some of the Magdalenian charcoal represents Holocene contamination, especially the presence of abundant beech.)

Such clear opposition between the nature of anthropogenic remains present in the Magdale-

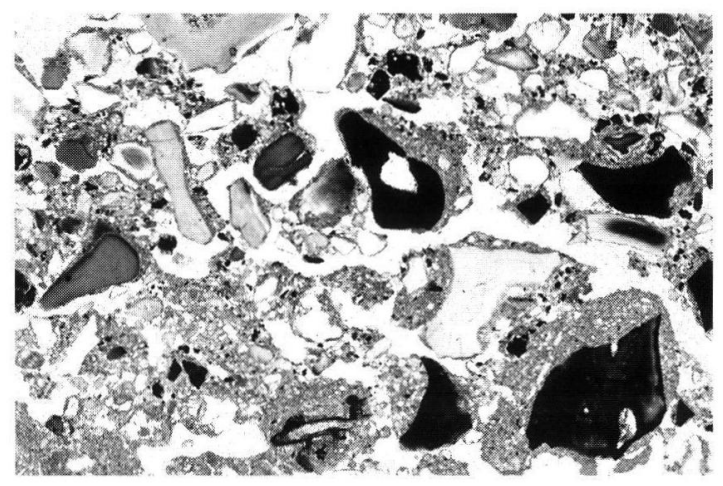

Fig. 21: Sample HF-9B (Layer 3bt).Microphotograph showing the concentration of burnt and unburnt bones mixed within a calcareous matrix which commonly coats the bones. This is most likely accumulated as dumped burned material (see SOLveig et al. 2003 for details). PPL; width of view, ca. $3.2 \mathrm{~mm}$. nian and the Gravettian occupation layers suggests different pyrotechnological strategies. The presence of burnt bone correlated with the absence of charcoal in Layer $3 \mathrm{~b}$ and partially in Layer 3c, probably indicates the use of bone as fuel during the Gravettian. Bone fuel use has already been demonstrated from the independent study of a thin layer within the Gravettian Unit (SchiEgl et al. 2003). Layer 3cf is a 3 to 10 $\mathrm{cm}$ thick very dark layer of mostly burnt bone. The micromorphological investigation of Layer $3 \mathrm{cf}$ concluded that there was no evidence of in situ burning and that the layer of burnt bone had been most likely deposited by dumping. Nevertheless, the extreme rarity of charcoal within the burnt bone Layer 3cf was confirmed. Our micromorphological examination of the Gravettian complex as a whole seems to confirm the choice of bone fuel over charcoal during the Gravettian occupation of the cave. Schiegl et al. (Schiegl et al. 2003) review the wealth of evidence for bone burning during the Middle Palaeolithic and Upper Palaeolithic of the Swabian Jura. On the contrary, during the Magdalenian occupation, there are fewer signs of use of bone fuel, but the presence of charcoal suggests use of regular wood as fuel.

Finally, Layer 3bt within the Gravettian sediments (Figure 4) was noteworthy in the sense that it contained a very high density of burnt bone. The micromorphological study demonstrated the anthropogenic/biogenic nature of Layer 3 bt within the Layer 3 b sediments, which are impoverished in charcoal. At least two of these dark pockets of burnt bone and charcoal were seen in the profile (only one of which was sampled for analysis; Figure 4). The burnt bone fragments range from slightly burnt to carbonized and microscopic fragments are mixed with larger unburned bone pieces (Figure 21). The few limestone clasts mixed with the densely packed burnt bone are unburnt and exhibit a capping similar to that observed in the Layer $3 \mathrm{~b}$ sediments, suggesting that the formation of Layer 3 bt took place during the Gravettian. 


\section{Phosphate}

Phosphatization of the matrix or fine fraction is relatively high both in the Gravettian sediments (layers $3 b$ and $3 c$ ) and the Magdalenian sediments (layers $1 \mathrm{k}$ and $0 \mathrm{c}$ ). The intervening sediments (layer 3a where present, is a mixed layer that separates $1 \mathrm{k}$ from the Gravettian $3 \mathrm{~b}$ layer), however, are markedly more phosphatized. Under ultraviolet light, the clay-rich matrix of Layer $3 c$ is homogeneously fluorescent, evidence of its highly phosphatized and decalcified nature. Although Layer $3 c$ includes roughly the same components - clay, silt, limestone, bone, and charcoal - as the layers above it, in Layer $3 c$ these elements are finer and more "worked into" the matrix, either by physical or chemical processes. As displayed in sample HF-3A, Layer $3 \mathrm{~b}$ contains a much coarser assortment of these components. This contact is visible at the macroscopic scale as well. In the field, $3 \mathrm{~b}$ was described as much siltier and sandier - relatively devoid of clay - than the ,argillaceous silt" of Layer 3c.

The key contact between Layers $3 \mathrm{c}$ and $3 \mathrm{~b}$ is also evident in the occurrence of large grains of phosphatic material in $3 \mathrm{~b}$ in contrast to the relatively homogeneous alteration of the matrix found in Layer 3c. Ultraviolet examination of sample HF-11, taken from the lower part of Layer $3 \mathrm{~b}$, revealed dense phosphatic grains. These grains could be the remnants of a phosphate crust derived from guano or other products of animal activity. The presence of intensive animal occupation would account for the increased phosphatization of Layer $3 \mathrm{c}$. The intensive human occupation and cryoturbation of $3 \mathrm{~b}$ could have broken up this crust, incorporating rounded fragments of dense phosphate within the overlying $3 \mathrm{~b}$ sediments, as found in sample HF-11.

The source of the phosphate is not totally clear. However, the abundance of bear remains from in the interior of the cave - which must have served as their hibernation home - would point to bear as a possible source of phosphate, either from the food they brought in or from their excrements. There is very good evidence for the intense use of the cave by bears during Gravettian times. Bones of cave bear are by far the most numerous, and the age profiles are dominated by young and old animals that usually die during hibernation (MünzEL et al. 2000). A number of $\mathrm{mm}$ to $\mathrm{cm}$ size pieces of carnivore coprolites was found in the thin sections. Although these are too small to identify as to specific animal, bears are a likely candidate. In any case, at this point the details of the geochemical and microenvironmental conditions responsible for decalcification and phosphatization of the matrix, movement of phosphatic solutions, and the formation of phosphate reaction rims around limestone clasts are not clear and are currently under study.

\section{Conclusion}

This preliminary study of the Magdalenian and Gravettian sediments at Hohle Fels demonstrates the potential of micromorphological study of archaeological deposits in cold regions, particularly this part of Germany which both underwent marked climatic change but also contains a rich record of prehistoric occupations. Although it is likely that no one methodological approach could hope to completely elucidate the complex arrangement of anthropogenic, biogenic, and geogenic elements deposited in this cave, micromorphological analysis provides information complementary to that gathered by traditional field and laboratory methods (COURTY et al. 1989). The Layer $3 \mathrm{c}$ sediments display platy structures indicative of more continuous cold conditions. While the overlying Layer $3 \mathrm{~b}$ sediments also contain some platy or lens-like structures, they are dominated by rounded cryoturbation aggregates. These grains indicate a greater frequency of freezel thaw cycles, a conclusion supported by the presence of cappings of fine material on large clasts and aggregates. From the anthropogenic perspective, both Layers $3 \mathrm{c}$ and $3 \mathrm{~b}$ are compat- 
ible with the use of bone as the primary fuel, while higher in the sequence, charcoal remains indicate the use of wood fuel instead (SCHIEGL et al. 2003).

Much of this preliminary work will be refined as more exposures - both vertical and lateral - become available at Hohle Fels. In addition, work at the contemporary site of Geissenklösterle about $2 \mathrm{~km}$ away will serve as a comparison to evaluate and extend the observations and interpretations made here. This study adds further evidence to the discussion of human responses to climatic change in the Upper Paleolithic. When results from the Middle Palaeolithic and earliest Upper Palaeolithic units from Hohle Fels and Geissenklösterle become available, we will have some very clear notions about the environmental background at this important transition in human history.

\section{Acknowledgments}

We would like to thank Philipp Drechsler, Kurt Langguth, Laura Niven, Andrew Kandel, Timothy Prindiville, and Kirsten Schell of the Institut für Ur- und Frühgeschichte und Archäologie des Mittelalters der Universität Tübingen for their assistance in collecting the unwieldy samples used in this study. Ilean Isaza assisted with collection of some of the micromorphological data.

\section{References}

Arpin, T. L., Mallol, C. \& Goldberg, P. (2002): A new method of analyzing and documenting micromorphological thin sections using flatbed scanners: applications in geoarchaeological studies. - Geoarchaeology: an International Journal, 17: 305-313; Boston.

Blumentritt, R. \& Hahn, J. (1991): Der Hohle Fels. - Schelklinger Archäologische
Führer 1; Blaubeuren: Schröder.

Burkert, W. \& Floss, H. (in press): Lithic exploitation areas in the Upper Paleolithic of West and Southwest Germany - a comparative study. VIII. - Flint Symposium; Bochum.

Campen, I. (1987). Die Sedimente der Höhlen und Abris der Mittleren Schwäbischen Alb und ihre klimatische Ausdeutung. - Doctoral dissertation; University of Tübingen.

Conard, N. J. \& Bolus, M. (2003): Radiocarbon dating the Appearance of Modern Humans and the Timing of Cultural Innovations in Europe: New Results and new Challenges. Journal of Human Evolution, 44: 331-371; Amsterdam.

Conard, N. J. \& Floss, H. (1999): Ein bemalter Stein vom Hohle Fels bei Schelklingen und die Frage nach paläolithischer Höhlenkunst in Mitteleuropa. - Archäologisches Korrespondenzblatt, 29: 307-316; Mainz.

Conard, N. J. \& Floss, H. (2000): Eine Elfenbeinplastik vom Hohle Fels bei Schelklingen und ihre Bedeutung für die Entwicklung des Junpaläolithikums in Süddeutschland. - Archäologisches Korrespondenzblatt, 30: 473-480; Mainz.

Conard, N. J. \& Floss, H. (2001): Neue EiszeitKunstwerke von der Schwäbischen Alb - In Kölbi, S. \& Conard, N. J. [Eds.]: Neue Eiszeit-Kunstwerke von der Schwäbischen Alb. Urgeschichtliches Museum Blaubeuren, Museumsheft 4: 21-34; Stadt Blaubeuren und Institut für Ur- und Frühgeschichte der Universität Tübingen; Tübingen.

Conard, N. J. , Langguth, K. \& Uerpmann, H. P. (2000): Die Ausgrabungen 1999 in den Gravettien-Schichten des Hohle Fels bei Schelklingen, Alb-Donau-Kreis. - Archäologische Ausgrabungen in Baden-Württemberg 1999: 21-25; Stuttgart.

Conard, N. J. , Langguth, K. \& Uerpmann, H. P. (2002): Die Ausgrabungen 2001 in den frühen junpaläolithischen Schichten im Hohle Fels bei Schelklingen, Alb-Donau- 
Kreis. - Archäologische Ausgrabungen in Baden-Württemberg 2001; Stuttgart.

Conard, N. J. \& Uerpanan, H. P. (1999): Die Ausgrabungen 1997 und 1998 im Hohle Fels bei Schelkingen, Alb-Donau-Kreis, - Archäologische Ausgrabungen in BadenWürttemberg 1998: 47-53; Stuttgart.

Courty, M. A. , Goldberg, P., and Macphail, R. I. (1989): Soils and Micromorphology in Archaeology. Cambridge Manuals in Archaeology; Cambridge: Cambridge University Press.

Courty, M. A. \& Valluerdou, J. (2001): The Microstratigraphic Record of Abrupt Climate Changes in Cave Sediments of the Western Mediterranean. - Geoarchaeology, 16 (5): 467-500; London.

Cremaschi, M. and Van Vliet-Lanoë, B. (1990): Traces of frost activity and ice segregation in Pleistocene loess deposits and till of northern Italy: deep seasonal freezing or permafrost? - Quaternary International, 5: 39-48; Amsterdam.

Fischer, B., Hahn, J. \& Saier, C. (1993): Ausgrabungen im Hohle Fels bei Schelklingen, Alb-Donau-Kreis. - Archäologische Ausgrabungen in Baden-Württemberg 1992: 38-40; Stuttgart.

Giluitison, D. (1997): Caves: Processes, Development and Management; Oxford, Blackwell Publishers.

Hahn, J. (1988): Die Geissenklösterle-Höhle im Achtal bei Blaubeuren I. Fundhorizontbildung und Besiedelung im Mittelpaläolithikum und im Aurignacien. - Forschungen und Berichte zur Vor- und Frühgeschichte in Baden-Württemberg. 26; Stuttgart.

Hahn, J. (1989a): Neue Grabungen im Hohle Fels Schelklingen, Alb-Donau-Kreis. - Archäologische Ausgrabungen in BadenWürttemberg 1988: 20-22; Stuttgart.

HAHN, J. (1989b): Zur Funktion einer Aurignacien-Feuerstelle aus dem Geissenklösterle bei Blaubeuren. - Fundberichte aus Baden Württemberg, 14: 1-21; Stuttgart.
HaHn, J. (1991): Höhlenkunst aus dem Hohle Fels bei Schelklingen, Alb-Donau-Kreis. - Archäologische Ausgrabungen in BadenWürttemberg 1990: 19-22; Stuttgart.

Hahn, J. (1992): Der Hohle Fels bei Schelklingen, Alb-Donau-Kreis - die Ausgrabungen 1991. - Archäologische Ausgrabungen in Baden-Württemberg 1991: 21-23; Stuttgart.

HaHn, J. (1995): Ausgrabungen 1994 im Hohle Fels Schelklingen, Alb-Donau-Kreis. - Archäologische Ausgrabungen in BadenWürttemberg 1994: 24-27; Stuttgart.

HAHn, J. \& PASDA, C. (1990): Spätquartäre Funde und Sedimente im Hohle Fels bei Schelklingen, Alb-Donau-Kreis. - Archäologische Ausgrabungen in Baden-Württemberg 1989: 21-24; Stuttgart.

Hofreiter, M. , Capeldi, C., Krings, M., Waits, L., Conard, N., Münzel, S., Rabieder, G., Nagel, D., Paunovic, M., Jambresić, G., Meyer, S., Weiss, G., \& PÄÄвo, S. (2002): Ancient DNA Analyses Reveal High Mitochondrial DNA Sequence Diversity and Parallel Morphological Evolution of Late Pleistocene Cave Bears. - Molecular Biology and Evolution, 19 (8): 1244-1250; Amsterdam.

Housley, R. A., Gamble, C. S., Street, M. \& Peтtiтt, P. (1997): Radiocarbon Evidence for the Late Glacial Recolonisation of Northern Europe, - Proceedings of the Prehistoric Society, 63: 25-54.

Laville, H. \& Hahn, J. (1981): Les dépots de Geißenklösterle et l'évolution du climat en Jura souabe entre 36,000 et 23,000 B. P., C. R. Acad. Sc. Paris, 292: 225-227; Paris.

Münzel, S., Langguth, K., Conard, N. J. \& Uerpmann, H. P. (2001): Höhlenbärenjagd auf der Schwäbischen Alb vor 30.000 Jahren. - Archäologisches Korrespondenzblatt, 31: 317-328; Stuttgart.

Obermaier, H. (1906): Les restes humains quaternaires dans l'Europe Central. La caverne du Hohlefels. - L'Anthropologie, 17: 62-63; Paris. 
Pissart, A., Van Vliet-Lanoë, B., Ek, C. \& Juvigne, E. (1988a): Traces of ice in caves: Evidence of former permafrost. - Permafrost, Fifth international conference, 5: 840-845.

Pissart, A., Van Vliet-Lanoë, B., Ek, C. \& Juvigne, E. (1988b): Des traces de glace de ségrégation dans la grotte de Remouchamps (Belgique): conséquences en ce qui concerne la sédimentation et la paléoclimatologie. - Annales de la Société géologique de Belgique, 111: 125-133; Brüssel.

RÄHLE, W. (1981): Schmuckschnecken aus jungpaläolithischen Fundschichten vom Hohle Fels bei Schelklingen (Alb-DonauKreis). - Archäologisches Korrespondenzblatt, 11: 179-180; Stuttgart.

SAiER, C. R. (1994): Das Material der "Altgrabungen" vom Hohlen Felsen, Gemeinde Scheklingen, Alb-Donau-Kreis. Masters Thesis; University of Tübingen.

SCHEer, A. (1994): Neue jungpaläolithische Funde aus dem Hohle Fels bei Schelklingen, Alb-Donau-Kreis. - Archäologische Ausgrabungen in Baden-Württemberg 1993: 24-27; Stuttgart.

Schiegl, S., Goldberg, P. \& Conard, N. J. (2003): Palaeolithic Burnt Bone Horizons from the Swabian Jura - Distinguishing Between in-situ Fireplaces and Dumping Areas. Geoarchaeology.

SснмiDT, R. R. (1910): Der Sirgenstein und die diluvialen Kulturstätten Württembergs. - Stuttgart.

SchmidT, R. R. (1912): Die diluviale Vorzeit Deutschlands. - Stuttgart.

Van Vliet-Lanö̈, B. (1982): Structures et microstructures associées à la formation de glace de ségrégation: Leurs conséquences. - 4th Canadian permafrost conference: 116-122; Ottawa.

Van Vliet-Lanö̈, B. (1985): Frost effects in soils. - In: BoArdman, J. [ed.]: Soils and Quaternary Landscape Evolution: 117-158; London (Wiley).

Van Vliet-Lanoe,
B. (1987):

Dynamique périglaciaire actuelle et passée. Apport de l'étude micromorphologique et de l'expérimentation. - Bulletin de l'Association francaise pour l'étude du quaternaire, 2: 113-132; Paris.

Van Vliet-Lanoë, B. (1991): Chronostratigraphy and paleoclimatic meaning of cryogenic deformations in the Central European Loess. - GeoJournal, 24: 157-163; Pordrecht.

Van Vliet-LanoË, B. (1998): Frost and soils: implications for paleosols, paleoclimates and stratigraphy. - Catena, 34: 157-183; New York.

Villinger, E. (1986): Untersuchungen zur Flußgeschichte von Aare-Donau/Alpenrhein und zur Entwicklung des Malmkarsts in Südwestdeutschland. - Jahreshefte des geologischen Landesamtes in Baden-Württemberg, 28: 297-362; Freiburg.

WAGNER, E. (1979): Eiszeitjäger im Blaubeurener Tal. - Führer zu archäologischen Denkmälern in Baden-Württemberg 6; Stuttgart. Weiner, S., Schiegl, S., Goldbberg, P. \& BarYosef, O. (1995): Mineral assemblages in Kebara and Hayonim Caves, Israel: Excavation strategies, bone preservation, and wood ash remnants. - Israel Journal of Chemistry, 35: 143-154; Jerusalem. 